\title{
High Performance Walls in Hot-Dry Climates
}

Marc Hoeschele, David Springer, Bill Dakin, and Alea German

Alliance for Residential Building Innovation 


\title{
NOTICE
}

This report was prepared as an account of work sponsored by an agency of the United States government. Neither the United States government nor any agency thereof, nor any of their employees, subcontractors, or affiliated partners makes any warranty, express or implied, or assumes any legal liability or responsibility for the accuracy, completeness, or usefulness of any information, apparatus, product, or process disclosed, or represents that its use would not infringe privately owned rights. Reference herein to any specific commercial product, process, or service by trade name, trademark, manufacturer, or otherwise does not necessarily constitute or imply its endorsement, recommendation, or favoring by the United States government or any agency thereof. The views and opinions of authors expressed herein do not necessarily state or reflect those of the United States government or any agency thereof.

Available electronically at http://www.osti.gov/bridge

Available for a processing fee to U.S. Department of Energy and its contractors, in paper, from:

\author{
U.S. Department of Energy \\ Office of Scientific and Technical Information \\ P.O. Box 62 \\ Oak Ridge, TN 37831-0062 \\ phone: 865.576 .8401 \\ fax: 865.576.5728 \\ email: mailto:reports@adonis.osti.gov
}

Available for sale to the public, in paper, from:

U.S. Department of Commerce

National Technical Information Service

5285 Port Royal Road

Springfield, VA 22161

phone: 800.553 .6847

fax: 703.605.6900

email: orders@ntis.fedworld.gov

online ordering: http://www.ntis.gov/ordering.htm 


\title{
High Performance Walls in Hot-Dry Climates
}

\author{
Prepared for: \\ The National Renewable Energy Laboratory \\ On behalf of the U.S. Department of Energy's Building America Program \\ Office of Energy Efficiency and Renewable Energy \\ 15013 Denver West Parkway \\ Golden, CO 80401 \\ NREL Contract No. DE-AC36-08GO28308 \\ Prepared by: \\ Marc Hoeschele, David Springer, Bill Dakin, and Alea German \\ Alliance for Residential Building Innovation (ARBI) \\ Davis Energy Group, Team Lead \\ 123 C Street \\ Davis, California 95616 \\ NREL Technical Monitor: Stacey Rothgeb \\ Prepared under Subcontract No. KNDJ-0-40340-05
}

January 2015 
The work presented in this report does not represent performance of any product relative to regulated minimum efficiency requirements.

The laboratory and/or field sites used for this work are not certified rating test facilities. The conditions and methods under which products were characterized for this work differ from standard rating conditions, as described.

Because the methods and conditions differ, the reported results are not comparable to rated product performance and should only be used to estimate performance under the measured conditions. 


\section{Contents}

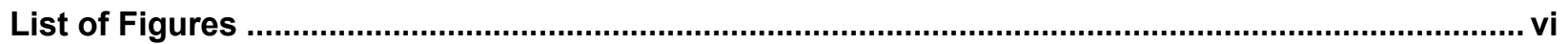

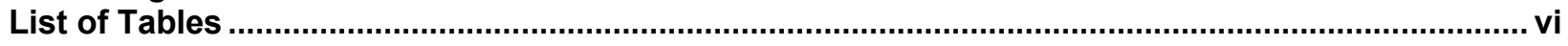

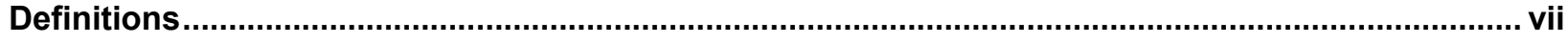

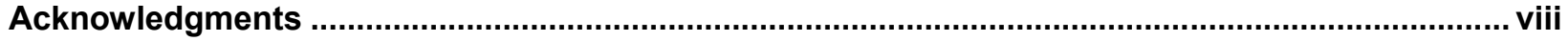

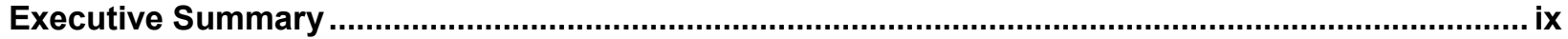

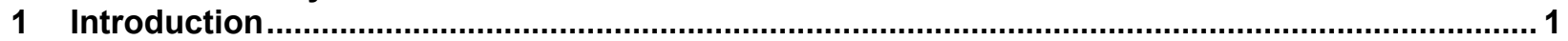

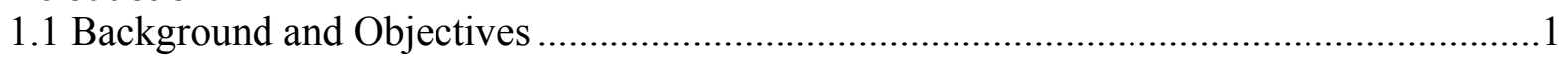

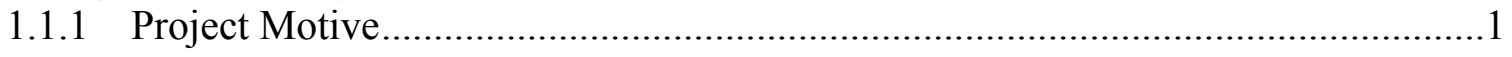

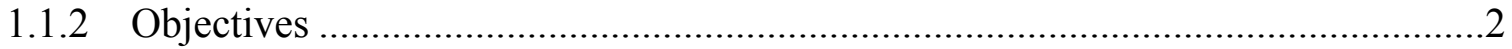

1.1.3 Prior High Performance Wall Research..........................................................2

1.1.4 Recent California Experiences With High Performance Walls ..............................

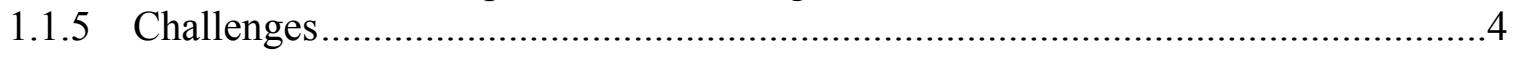

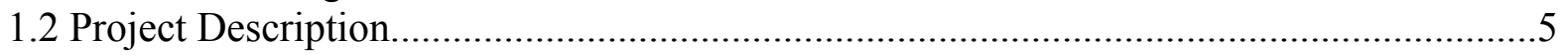

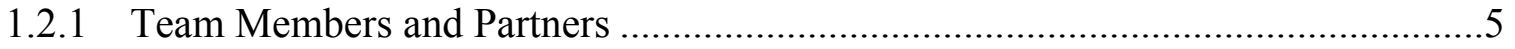

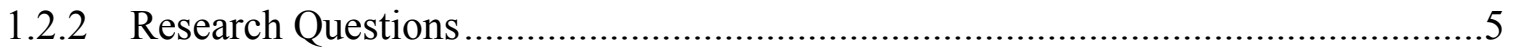

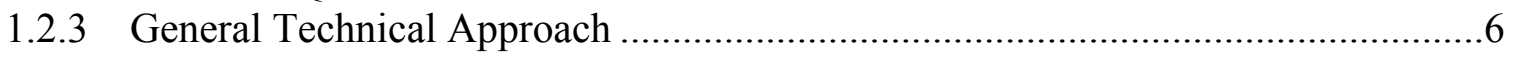

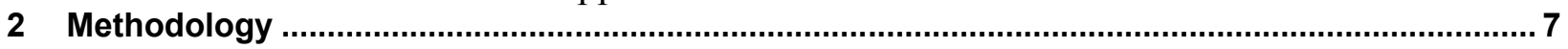

2.1 Builder Recruitment and House Selection Process....................................................... 7

2.2 Field Methods, Data Gathering, and Coordination .......................................................

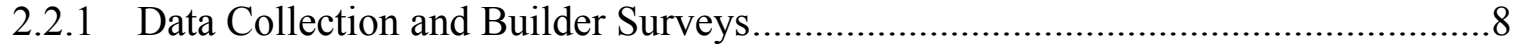

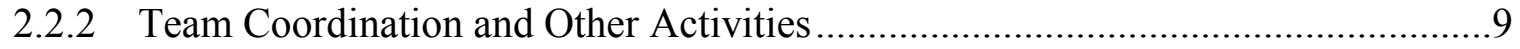

2.3 Evaluation Methods .............................................................................................

2.3.1 General Methods: Testing or Simulations?....................................................

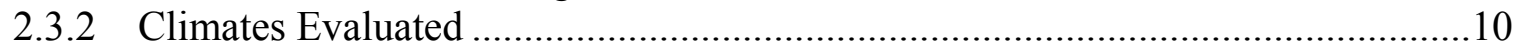

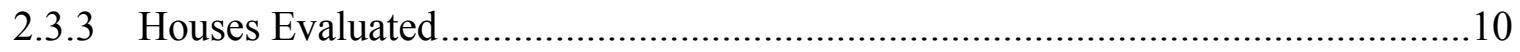

2.3.4 Wall Types Evaluated ............................................................................... 10

2.3.5 Costs and Performance for High Performance Wall Systems ............................11

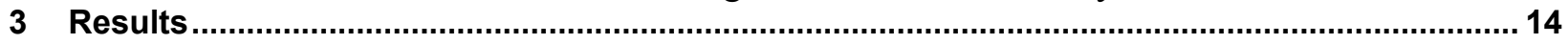

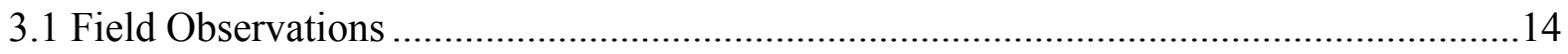

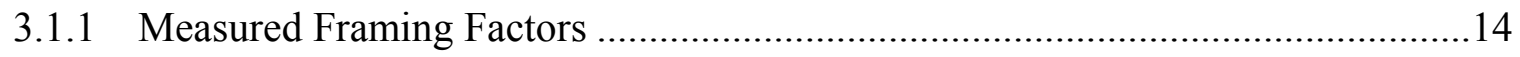

3.1.2 High Performance Wall System Framing Methods ..........................................14

3.1.3 General Observations and Risk Factors ....................................................... 17

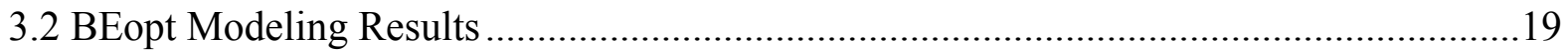

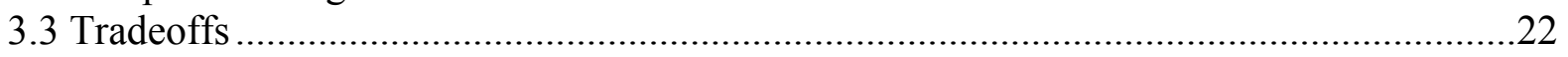

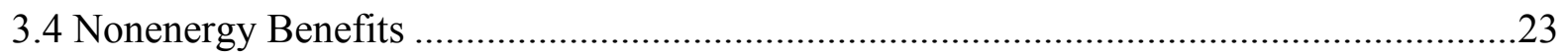

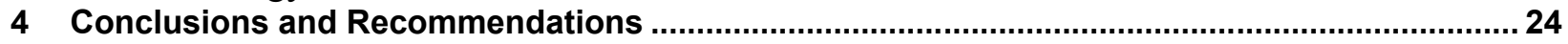

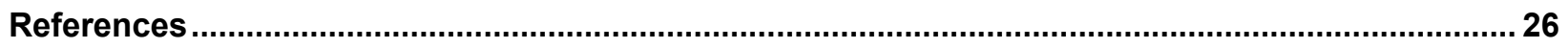

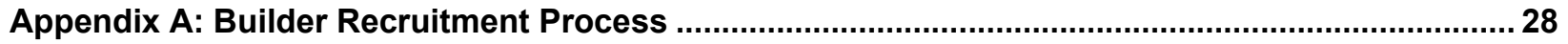

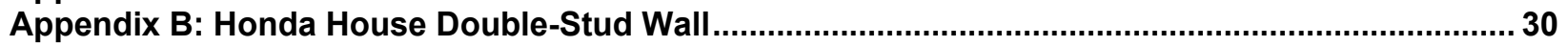

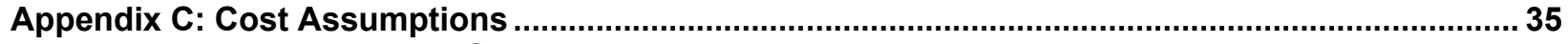

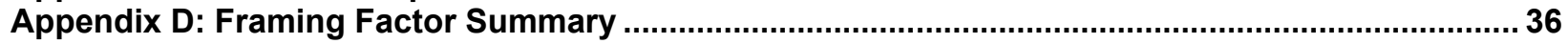

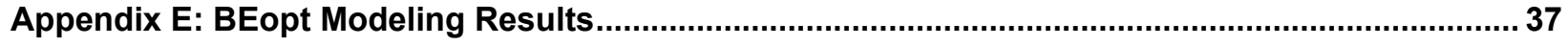




\section{List of Figures}

Figure 1. Example of excessive framing at windows (recessed in $2 \times 6$ wall)................................ 14

Figure 2. Wathen Castanos' high performance framing techniques ................................................. 15

Figure 3. Outside corner and intersecting wall details ................................................................ 15

Figure 4. Northwest Homes framing examples......................................................................... 16

Figure 5. GJ Gardner's wall details-24 in. on-center framing and double top plates ...................... 17

Figure 6. Least-cost curve for alternative wall systems $\left(2,100-\mathrm{ft}^{2}\right.$ prototype) ................................ 20

Figure 7. Least-cost curve for alternative wall systems $\left(2,700-\mathrm{ft}^{2}\right.$ prototype) ................................ 21

Figure 8. Aggregated HVAC source energy savings by climate and wall configuration ..................21

Figure 9. Annualized cost comparison of PV system to high performance walls ............................ 22

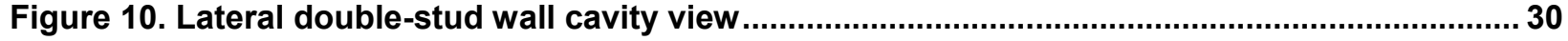

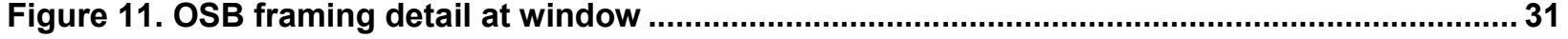

Figure 12. OSB board window perimeter connection ................................................................ 31

Figure 13. Great room double-stud wall with $1 / 4$-in. air gap between interior and exterior framing.. 32

Figure 14. Wall section framing factors (full assembly, exterior, interior)....................................... 32

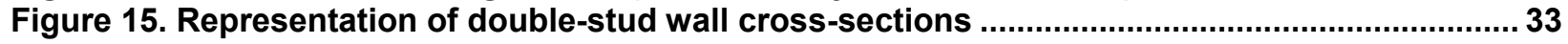

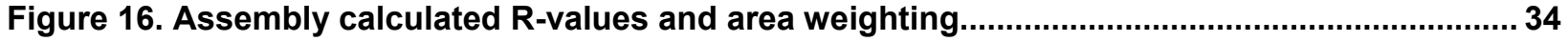

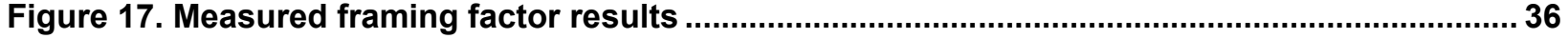

Unless otherwise noted, all figures were created by the ARBI team.

\section{List of Tables}

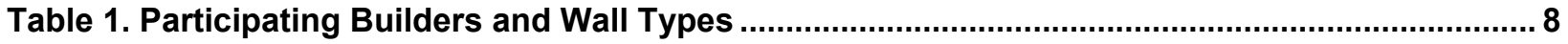

Table 2. Climate Details of Locations Used in Analysis ................................................................ 10

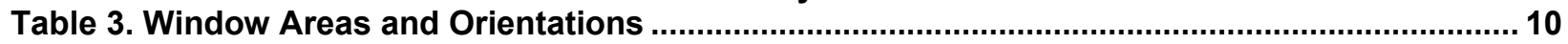

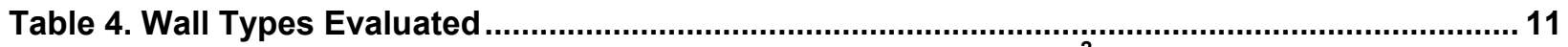

Table 5. High Performance Wall Incremental Costs (Over the $\$ 7.85 / \mathrm{ft}^{2}$ Base Case $2 \times 4$ R-13 Wall) 12

Table 6. High Performance Wall Assembly U-Value................................................................. 13

Table 7. Builders Contacted Who Chose Not To Participate ............................................................... 29

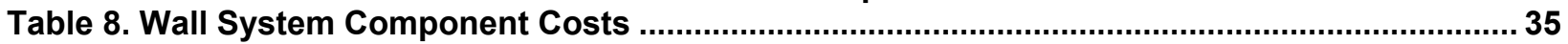

Unless otherwise noted, all tables were created by the ARBI team. 


\section{Definitions}

\begin{tabular}{|c|c|}
\hline ARBI & Alliance for Residential Building Innovation \\
\hline BEopt $^{\mathrm{TM}}$ & Building Energy Optimization Software \\
\hline BIB & Blown in Blanket \\
\hline CAHP & California Advanced Home Program \\
\hline CASE & Codes and Standards Enhancement project \\
\hline CEC & California Energy Commission \\
\hline EPS & Expanded Polystyrene \\
\hline HERS & Home Energy Rating System \\
\hline HVAC & Heating, Ventilation, and Air Conditioning \\
\hline IECC & International Energy Conservation Code \\
\hline IOU & Investor-Owned Utility \\
\hline NAHB & National Association of Home Builders \\
\hline PG\&E & Pacific Gas \& Electric \\
\hline o.c. & On Center \\
\hline OSB & Oriented Strand Board \\
\hline QII & Quality Insulation Installation \\
\hline RECS & Residential Energy Consumption Survey \\
\hline SCE & Southern California Edison \\
\hline STEM & Short Term Energy Monitoring \\
\hline $\mathrm{UC}$ & University of California \\
\hline XPS & Extruded Polystyrene \\
\hline ZNE & Zero Net Energy \\
\hline
\end{tabular}




\section{Acknowledgments}

The Alliance for Residential Building Innovation team acknowledges the support of the Pacific Gas \& Electric Company in providing the foundation on which this work was based. With Pacific Gas \& Electric support from the Emerging Technologies group and the Codes and Standards team, Alliance for Residential Building Innovation was able to assemble a strong team for conducting the necessary assessments and evaluations to complete this study. We would also like to acknowledge our builder partners who provided access to jobsites and vital information on costs and construction feedback related to implementation of high performance wall systems. 


\section{Executive Summary}

High performance walls are a high priority measure in moving the next generation of new homes to the zero net energy (ZNE) performance level. According to the U.S. Department of Energy's 2009 Residential Energy Consumption Survey (RECS 2013), national average household space heating energy use amounts to 38.7 million Btu/year, or $43 \%$ of household site energy consumption. The primary goal in improving wall performance revolves around increasing the thickness of the wall cavity beyond the standard $2 \times 4$ framing typically used, adding more cavity and exterior rigid insulation, achieving insulation installation criteria meeting the ENERGY STAR ${ }^{\circledR}$ thermal bypass checklist, and reducing the amount of wood penetrating the wall cavity. All of these measures are achievable and some will actually reduce construction costs.

California, as part of its continual movement to ZNE new construction by 2020, is considering making high performance exterior walls a prescriptive measure for the 2016 Title 24 building energy standards. Although according to the Residential Energy Consumption Survey, walls in "mixed-dry/hot-dry" climate regions contribute only $\sim 18.2$ million Btu/year to household consumption, they are a key component to California's vision for a 2020 ZNE new home. Current Title 24 pre-rulemaking proposals are evaluating prescriptive requirements for wall performance with effective U-values in the 0.046 to $0.050 \mathrm{Btu} / \mathrm{h}-\mathrm{ft}-{ }^{\circ} \mathrm{F}$ range (equivalent to $2 \times 6$ construction, 16 in. on center [o.c.] framing, R-23 cavity insulation, and R-4 rigid exterior insulation). To support this activity, in 2013 the Pacific Gas \& Electric Company initiated a project with Davis Energy Group (lead for the U.S. Department of Energy's Building America team, Alliance for Residential Building Innovation) to solicit builder involvement in northern and central California to participate in field demonstrations of high performance wall systems. Builders were given incentives and design support in exchange for providing site access for construction observation, cost information, and builder survey feedback. Information from the project was designed to feed into the 2016 Title 24 process, but also to serve as an initial mechanism to engage builders in more high performance construction strategies.

This Building America project utilized information collected in the California project to develop inputs and cost information for Building Energy Optimization (BEopt ${ }^{\mathrm{TM}}$ ) software simulations for a range of wall types. Double-stud and $2 \times 6$ wall construction (both 16 in. and 24 in. o.c.) with varying cavity and exterior insulation levels were modeled in four hot-dry climates: Sacramento, Fresno, Albuquerque, and Phoenix. Simulations were completed relative to a 2009 International Energy Conservation Code compliant wall construction. All of the high performance wall systems were found to have lower annualized energy-related costs than the benchmark wall in all climates, although the double-stud wall cost effectiveness was considerably worse than the $2 \times 6$ options. BEopt results suggest that there are a range of wall types available to builders to meet a U-value of 0.050 or better. 24 -in. o.c. framing and other high performance techniques are not necessarily required, nor is exterior insulation thicker than 1 in.

Builder feedback from the field suggests some level of interest in moving toward $2 \times 6$ construction, but also concern that the market doesn't value the technology or the potential benefits. In fact, some builders have received feedback from buyers that more high performance 24 in. o.c. framing is perceived as a "cheaper" wall, suggesting education is needed. Education and training for builders, homebuyers, architects, and subcontractors are important components in moving this initiative forward. 


\section{Introduction}

\subsection{Background and Objectives}

\subsubsection{Project Motive}

This project was inspired by the opportunity to influence California building energy standards related to high performance walls, and to identify and evaluate in the field potentially costeffective approaches to constructing high R-value walls, given the conditions that California builders face. These conditions include availability and cost of materials, structural requirements, codes and standards, local construction practices, market factors, and the level of training and conventional wisdom of the various trades involved in wall construction and assembly.

Enacted in 1974, the Warren-Alquist Act created the California Energy Commission (CEC) and provided for the state to create and periodically update energy standards. These standards, which fall under Title 24, Part 6 of the California Code of Regulations, have saved Californians more than $\$ 74$ billion in reduced electricity bills since 1977 and are significant factors in California's per capita electricity usage remaining flat over the last 40 years while the rest of the country's use continued to rise. The Title 24 building energy standards are updated about every 3 years through a process that develops Codes and Standards Enhancement (CASE) reports that propose particular measures for adoption. These CASE reports represent the basis for outside stakeholders and interested parties to react to proposals during the course of the pre-rulemaking process. The CASE reports are required to demonstrate that measures are cost effective and are vetted through public workshops and input to draft standards before the measures are adopted.

The California Public Utilities Commission allocates part of the funds that are collected by investor-owned utilities (IOUs) as "public goods" surcharges toward standards research and development of CASE reports. One of the measures chosen by the Statewide Investor Owned Utilities (IOU) Codes and Standards Team for potential inclusion in the 2016 standards rulemaking is "high performance walls." Pacific Gas \& Electric Company (PG\&E), as a core member of the IOU team, selected Davis Energy Group (DEG) to conduct research supporting the development of a CASE report on this topic, and the Alliance for Residential Building Innovation (ARBI) team saw the opportunity to leverage this work to help transform the California construction market in advance of the 2016 standards process, and to develop information that potential U.S. Department of Energy Zero Energy Ready builders and other progressive builders could apply.

Consequently, the project approach and methodology was guided by two objectives: (1) the development of information that will influence California codes and standards, and (2) meeting Building America research priorities. The U.S. Department of Energy's FY 2014 Residential System Research Needs, Item \#1 asks:

"What are the most cost effective, most durable and easiest to implement options for high $\mathrm{R}$ envelopes in new and existing homes?"

The project also responds to the National Renewable Energy Laboratory's 2013 Building America Technical Innovations Leading to 50\% Savings - A Critical Path, which sets as a goal in Item E6 to: 
"Develop guidance on design methods for enclosure design with a focus on above-grade walls; guidance to be provided for both new construction and retrofits in all U.S. climate zones."

\subsubsection{Objectives}

The primary goal of this project was to gather information in support of a Title 24 building energy code change proposal. Additionally, this project worked with multiple builders to provide guidance on framing methods and structural issues from local industry experts, offered construction methods developed and used successfully by builders in other locations, learned from local builders what the particular risks and challenges are, and worked with them on ways to overcome the challenges. The project sought to solve the puzzle of how to build thermally superior walls that meet builders' cost criteria, that require limited retraining of framing crews, and that comply with California's unique building codes and structural requirements within the context of the California building environment. The project defined a high performance wall as one having a composite U-value of $0.050 \mathrm{Btu} / \mathrm{h}-\mathrm{ft}^{2}-\mathrm{F}^{\circ}(\mathrm{R}-20)$ or better. One example is a $2 \times 6$ wall with R-23 cavity insulation and R-4 exterior continuous insulation. Other strategies that may be applied include double-stud walls, advanced framing, and alternative walls systems such as structurally insulated panels (SIPs).

\subsubsection{Prior High Performance Wall Research}

High performance wall research has been underway for many years, with Building America supported efforts playing a central role in evaluating thermal performance, developing design details, and solving wall durability issues (DeRenzis and Kochkin 2013; Straube and Smegal 2009; Steven Winter Associates 2011; Lstiburek 2004; Lstiburek and Grin 2010). These efforts in promoting high performance walls have been recognized by NAHB Research Center builder survey data, which show an increasing use of $2 \times 6$ framing (DeRenzis et al. 2013). Building America teams have been researching preferred methods for improving wall insulation by using more advanced framing techniques, applying exterior foam sheathing to stud walls, and using SIPs (Straube 2011; Lstiburek 2008). Construction details, particularly methods for fastening cladding to exterior foam thicker than $1 \mathrm{in}$. and methods for flashing windows, have been developed, but more work is needed to identify the incremental costs and benefits in hot-dry climates, particularly in the California building environment.

From an energy and resource efficiency perspective, "advanced framing" optimal value engineered techniques develop by NAHB in the 1970s strive to minimize the wood content of exterior walls while maintaining structural integrity, and to eliminate the common details that are thermally inefficient and challenging to insulate. These elements have been common knowledge to building scientists for several decades and were nicely summed up by Martin Holladay in a post to Green Building Advisor (Holladay 2010):

- Design walls around a 2-ft module (impacts architecture and layout).

- Switch from 16 in. o.c. framing to 24 in. o.c. framing for joists, studs, and rafters.

- Stack the wall, floor, and roof framing so that rafters, studs, and joists all line up.

- Switch from double top plates to single top plates joined with steel strapping or splice plates. 
- Get rid of jack studs; instead, support headers with steel clips (Simpson HH header hangers).

- Omit headers on gable walls and other non-loadbearing walls, and make sure headers are right-sized.

- Switch from three-stud corners to two-stud corners with drywall clips.

- Use ladder blocking at partition intersections.

- In some cases, omit structural wall sheathing and substitute T-profile diagonal steel bracing.

- If you have to seek out a framing crew with advanced framing experience, your labor costs may actually be higher.

Over the years the construction industry has realized that the fundamentals of advanced framing are generally most easily applied to simple floor plans. In the field, it can be surprisingly difficult to implement these strategies for the following reasons:

- Trend toward architectural design complexity in production homes

- Understanding (or misunderstanding) of codes by builders and building inspectors

- California's seismic design requirements

- Building industry inertia and risk aversion.

For example, it can be difficult to show lumber savings for 24-in. o.c. framing when walls are cut up by windows, doors, and corners, and when complicated roof structures make alignment of trusses and studs problematic. As pointed out by Holladay, there are many other challenges, including higher costs for design, planning, and supervision, possibly higher labor costs and lower productivity, higher material costs for custom stud lengths and framing anchors, difficulty attaching siding, and perception of 24 -in. spaced stud walls as substandard. ${ }^{1}$

Double-stud walls offer an alternative approach. By installing two $2 \times 4$ walls on a larger sill plate, framers can utilize standard framing techniques with minimal complications other than window and door treatments. A thicker wall cavity and elimination of much of the stud thermal bridge allows for greater cavity insulation. The primary disadvantages of this approach are added costs, impact on usable floor area, and potential moisture concerns, which are primarily focused in cold and very wet climates.

\subsubsection{Recent California Experiences With High Performance Walls}

The IBACOS Building America team was recently working with K. Hovnanian in California to improve the thermal performance of exterior walls in new production homes (IBACOS 2013). In northern California, insulated sheathing is the preferred method for eliminating the thermal bridging created by studs, plates, and headers, and can also contribute to airtightness. IBACOS looked at changing the 1-in. expanded polystyrene board (EPS) used with the builder's one-coat stucco system to either R-5 extruded polystyrene (XPS) or R-6.5 polyisocyanurate. When

\footnotetext{
${ }^{1}$ That 24-in. o.c. stud spacing is being viewed by some buyers as substandard was recently confirmed by one of our builder partners. Anecdotally, there is a perception that less wood is cheaper.
} 
reviewed with the stucco contractor, it was determined that neither of these alternative exterior sheathings had been approved for use with the stucco system as a fire-rated assembly. Without additional testing and listings, neither of these options could be applied. The CEC is pursuing evaluating alternative insulation materials including XPS and polyisocyanurate with the expectation that if the measure is vetted and approved during the current 2016 Title 24 process, the industry will quickly move to obtain the necessary certifications given the large market opportunity in California.

A more recent Southern California Edison (SCE) Emerging Products project reported on the design and construction of a ZNE house in coordination with builder Brookfield Homes (SCE 2014). One of the features implemented in the project was high performance wall framing. Other homes in this subdivision located in Ontario, California, were being framed with $2 \times 6$ on 16 in. centers. For the $1,828-\mathrm{ft}^{2}$ two-story ZNE house, the plan was to utilize 24 in. o.c. framing as well as other advanced framing concepts. The framer was at first very resistant to changing his framing practice because it would require retraining his framing crew. The framer originally intended to absorb the added cost of the framing material, just so he wouldn't have to retrain his crew. Teamed with an experienced construction consultant well versed in high performance wall systems, the framer was shown that, with small changes in framing practice, substantially less wood could be used and framing could move faster. The equivalent of about 40 full-length wall studs per floor were eliminated from the framing without compromising structural integrity. The impact on wall framing factor was to reduce it from $26.7 \%$ with $2 \times 616$-in. o.c. framing in a nearly identical "base" house, to $18.6 \%$ using the improved framing techniques.

SCE's experiences working with the builder and subcontractors also highlight an issue that is not uncommon as industries are beginning to adopt new practices. In this ZNE project, SCE was mindful of the fact that it did not want to adversely impact the work flow on the construction site. As a result, some of the more aggressive advanced framing measures were not implemented. Future rollout of these advanced measures will likely have to be addressed within the context of the builders' and subcontractors' experience and comfort level with the technology.

\subsubsection{Challenges}

Even though high performance wall construction techniques have been around for a while and are well documented, certain challenges remain. For example, stucco exterior finish represents almost all new construction in California. Exterior foam sheathing is an integral component of one-coat stucco systems, while three-coat stucco is typically applied without exterior foam. Historically, there have been perceived quality and durability issues with one-coat stucco among many builders and stucco contractors, primarily in southern California. There is a common perception that one-coat stucco systems are more susceptible to water intrusion, an outfall of several class-action law suits in California in the 1990s. While these issues were related to flashing around windows and not unique to one-coat stucco installation methods, some builders are still wary about using one-coat stucco systems. Many builders have also been reluctant to switch from three-coat to one-coat stucco for durability reasons; three-coat stucco is more resistant to cracking and damage from external forces. The recent change in the Title 24 energy code that includes exterior foam sheathing in prescriptive requirements will tend to push California builders to move toward one-coat systems. 
Identifying builder costs for these alternative wall construction techniques also can be challenging. Builders and subcontractors are often reluctant to share pricing information. In demonstration projects such as those supported by utilities, costs are typically inflated. Subcontractors see these "one-off" projects as both an unwelcome complication and an opportunity to apply change order pricing that may more than cover their costs. An understanding of true mature costing is generally realized only after the measure has achieved a high level of comfort with the builder and subcontractors, and can be competitively bid with multiple houses in the proposal. One recent study in the Pacific Northwest (Earth Advantage 2013) provides additional information to evaluate wall incremental costs based on surveys of 23 builders who have experience implementing high performance strategies.

Retraining the framing industry is also clearly a challenge that must be addressed. Framers represent one of many building trades that have relied on methods that have evolved little over recent decades. Often the builder's contractual relationship with the framer is to provide only the labor to complete the framing of the building envelope. With no incentive to conserve materials, simple, easily taught framing principles are passed down through the ranks. Changing these practices represents a major challenge in the pursuit of high performance and resource-efficient wall systems.

\subsection{Project Description}

\subsubsection{Team Members and Partners}

Managed by ARBI team lead DEG, the project benefitted from the participation of numerous highly qualified participants:

- Stuart Tartaglia and Marshall Hunt of PG\&E provided project management and technical review.

- Rick Chitwood of Chitwood Energy Management - who wears multiple hats as a performance contractor, building scientist, educator, and consultant to the Energy Commission — completed field observations to inspect construction techniques and document framing factors, and consulted with builder field staff.

- Jon McHugh of McHugh Energy is a consultant to PG\&E on its codes and standards activities.

- Tim Sloan, a registered structural engineer with Harris \& Sloan, has experience with advanced wall system design and provided guidance to the team and support to participating builders.

- Ken Nittler of Enercomp provided high-level Title 24 modeling support.

- Greg Barker and Ed Hancock of Mountain Energy Partners consulted on aspects related to potential wall thermal testing.

- Allen Amaro, a Home Energy Rating System (HERS) rater, provided support for field data collection activities.

\subsubsection{Research Questions}

This project was structured to provide answers to the following specific questions: 
1. What energy savings result from implementing high performance walls in the houses evaluated, and how reliable are the estimates?

2. Which implementation methods are most cost effective and builder acceptable in western hot-dry climates?

3. What are the risk factors and implementation issues identified in the field?

\subsubsection{General Technical Approach}

The following outlines the general technical approach that was developed to respond to the research questions:

- Identify builders and projects that would serve as candidates for evaluation, and secure commitments.

- Provide guidance on framing methods and structural issues as needed.

- Use stud counts and framing takeoffs to develop precise wall framing factors.

- Gather photographic and narrative information documenting framing and insulation construction practices, both good and bad.

- Assess wall performance using the Building Energy Optimization (BEopt ${ }^{\mathrm{TM}}$ ) simulation tool and information gathered.

- After implementation, gather cost data and builder feedback on implementation issues, risk factors, and other installation related issues.

- Determine the relative cost-benefits of the various wall designs and develop recommendations based on this information, relative ease of execution, and risk factors.

- Utilize project information to develop guidelines for hot climates.

The use of Short Term Energy Monitoring (STEM) tests for field evaluating wall performance was briefly considered at the onset of the project in mid-2013. However, after a review of the opportunity with Greg Barker and Ed Hancock, the STEM test was abandoned. Preliminary simulation efforts to isolate the wall thermal conduction component from ceiling, floor, and window conduction and infiltration suggested that in the relatively mild California climate, it would be impractical and beyond the limits of measurement accuracy to try to resolve field impacts of high performance versus conventional wall construction using the STEM approach. Hence, it was resolved that detailed modeling using BEopt would be the evaluation tool used to compare the performance of various wall system options.

The participating builders were attentive to the information provided by the team on high performance wall options, but each had a slightly different approach and receptiveness to different strategies. Construction methods and details were reviewed, and assistance was provided to builders and architects as needed to ensure application of best practices and to avoid pitfalls. The methodology described in the next section provides more detail on the technical approach and how information was gathered and evaluated. 


\section{Methodology}

\subsection{Builder Recruitment and House Selection Process}

To encourage builder participation, PG\&E offered incentives to the participating builders who would build homes with high performance walls having a composite U-value of $0.050 \mathrm{Btu} / \mathrm{h}-\mathrm{ft}^{2}$ $\mathrm{F}^{\circ}$ or better, ${ }^{2}$ as well as sharing site access, providing cost data, and a final debriefing phone call. In coordination with PG\&E, DEG presented a webinar on July 15, 2013, to introduce major California HERS raters and builders participating in the California Advanced Home Program (CAHP) to the utility's emerging technology program opportunity. DEG also announced the opportunity to its Building America builder partners, Leadership in Energy \& Environmental Design for Homes contacts, the California Association of Building Energy Consultants, and builders attending the Pacific Coast Builders Conference and California Building Industry Association meetings.

In some cases, builders were already constructing walls that met or were close to meeting the specification, but generally the recruitment process required talking through the wall design requirements and options, providing information on the expected benefits (using a beta version of the new California 2013 Title 24 compliance software), and working through their business decision frameworks. The 19 builders to whom the opportunity was presented reviewed the offer internally, requested additional information, in some cases held discussions with subcontractors to determine capabilities, and estimated costs.

Builders participating in the project were provided with consulting support and incentives to help offset incremental costs, coordinate site access during construction, and promote cooperation during cost and other information-gathering efforts. Between the High R-value Walls project and a companion PG\&E Ducts in Conditioned Space project, the team contacted approximately 20 builder prospects (list of builders contacted is provided in Appendix A). A small set of four builders decided to formally participate, while a few others permitted informal site data collection without committing to the more involved effort associated with providing cost data and builder survey feedback. Reasons for not participating included insufficient staff to handle the intricacies of a one-off design in a production environment, lack of interest in sharing costs, and timing constraints of completing a house within the project schedule. Builders and houses involved in the study are listed in Table 1, with one builder listed anonymously.

In addition to these builders, framing information was obtained from the Honda Smart House. This ZNE research house, constructed at the University of California Davis West Village community, was completed in early 2014 and featured a double-wall construction with studs on 24 -in. centers, nailed to $2 \times 10$ top and bottom plates. The 9-1/4-in. wide wall cavity was filled with cellulose insulation.

\footnotetext{
${ }^{2}$ Incentives were also offered to builders willing to locate ducts in conditioned space.
} 
Table 1. Participating Builders and Wall Types

\begin{tabular}{|c|c|c|c|}
\hline Builder & Location & Wall Construction & Additional Notes \\
\hline $\begin{array}{l}\text { Wathen } \\
\text { Castanos }\end{array}$ & Fresno & $\begin{array}{l}2 \times 6,16 \text { in. o.c., R-23 } \\
\text { with } 1 \text { in. of exterior } \\
\text { EPS foam }\end{array}$ & $\begin{array}{l}\text { Has worked on high performance homes with } \\
\text { IOUs and under Building America program. } \\
\text { Required a departure from its normal wall } \\
\text { construction practice. }\end{array}$ \\
\hline $\begin{array}{c}\text { GJ } \\
\text { Gardner }\end{array}$ & Sanger & $\begin{array}{l}2 \times 6,24 \text { in. o.c., R-19 } \\
\text { with } 1 \text { in. of exterior } \\
\text { EPS foam }\end{array}$ & $\begin{array}{l}\text { Franchise builder, typically exceeding } \\
\text { California code. Required a departure from } \\
\text { its normal wall construction practice. }\end{array}$ \\
\hline $\begin{array}{l}\text { Northwest } \\
\text { Homes }\end{array}$ & Redding & $\begin{array}{l}2 \times 6,16 \text { in. o.c., } \mathrm{R}-23 \\
\text { with } 1 \text { in. of exterior } \\
\text { EPS foam }\end{array}$ & $\begin{array}{l}\text { Small regional builder with experience } \\
\text { working with } 2 \times 6 \text { walls. Team worked with } \\
\text { builder to implement design. }\end{array}$ \\
\hline $\begin{array}{l}\text { Honda } \\
\text { Smart } \\
\text { Home }\end{array}$ & Davis & $\begin{array}{l}\text { Double } 2 \times 4 \text { stud wall } \\
\text { on } 2 \times 10 \text { plate, } \\
\text { nominal } 24 \text { in. o.c. on } \\
\text { exterior wall; R-33 } \\
\text { blown cellulose in wall } \\
\text { cavity }\end{array}$ & $\begin{array}{l}\text { The Honda Smart Home is located on the } \\
\text { University of California Davis West Village } \\
\text { ZNE Community and represents an } \\
\text { innovative integrated systems design } \\
\text { approach combining energy-efficient } \\
\text { technologies, renewable generation, and } \\
\text { advanced battery technology. }\end{array}$ \\
\hline
\end{tabular}

\subsection{Field Methods, Data Gathering, and Coordination}

\subsubsection{Data Collection and Builder Surveys}

Site inspections were employed to gather detailed data on insulation levels, method and quality of insulation installation, stud/framing counts and spacing, and observation of other construction details such as wall intersections, corners, headers, and plates. The intent was to use the data collected to support BEopt evaluations to estimate the impact of the wall design on building energy use. However, as described in Section 2.3, a broader set of wall design options was evaluated. BEopt inputs include wall framing materials, stud type spacing (single stud, double stud), framing factor, exterior sheathing type and R-value (none, oriented strand board [OSB], or rigid foam), and cavity insulation R-value and installation quality. Cavity insulation quality and degradation assumptions for California differ from the assumption used in BEopt and used in the Residential Energy Services Network. ${ }^{3}$

Information on incremental costs, implementation barriers, etc. was gathered through site visits, meetings, and communications with builders and contractors as listed below.

- Incremental cost for the high performance wall system relative to builders' current practice (in California, nominally $2 \times 4$ with R-13 cavity insulation, and R-4 exterior foam), including:

\footnotetext{
${ }^{3}$ The California Quality Insulation Installation (QII) inspection allows HERS raters to certify that a wall and ceiling meet the criteria of "proper" insulation installation and draftstopping. For exterior walls, a non-QII wall is modeled with a 30\% degradation in cavity R-value (versus $0 \%$ for QII). Although not directly comparable, the California degradation compares to the $2 \%-5 \%$ RESNET void assumption for a Grade 3 wall.
} 
- Incremental cost of framing materials

- Added framing subcontractor labor cost

○ Added insulation subcontractor cost.

- Difficulties encountered by builder, framer, and other trades that are atypical of standard practice, and any other anecdotal information related to the implementation of high performance framing, including perceived risks.

- Performance estimates of the proposed measures relative to both the 2009 International Energy Conservation Code (IECC) and 2008 California Title 24 standard energy budgets

- Pros and cons of the wall system including but not limited to:

- Level of effort to coordinate with other trades and other components of the home

○ Difficulty of properly installing the measure

$\circ$ Changes to the building design that would facilitate installation of the measures.

\subsubsection{Team Coordination and Other Activities}

DEG coordinated with PG\&E to execute builder access agreements with the participating builders and facilitated payment of the builder incentives. DEG also hosted bimonthly project calls with PG\&E and other participants, conducted meetings with builders, coordinated site inspections, and reviewed field data. DEG worked closely with the energy consulting firm TRC in supporting its pre-rulemaking activities related to high performance wall system for the 2016 Title 24 cycle. ${ }^{4}$

\subsection{Evaluation Methods}

\subsubsection{General Methods: Testing or Simulations?}

DEG, the National Renewable Energy Laboratory, and the project team were in agreement that STEM tests would not yield sufficient resolution to accurately distinguish the performance impacts of high performance wall designs. ${ }^{5}$ The performance of a wall system can be tested in a laboratory setting using a guarded hot box procedure, and this provides value as a steady-state snapshot for a particular section of wall. However, of most interest for this research is to evaluate the annual and life cycle impacts of various wall designs, which are dependent on field installation details, climate, diurnal temperature variations, internal gains, and other factors that are difficult to mimic in controlled laboratory settings. Short of completing highly expensive long-term monitoring of identical side-by-side buildings with identical operating profiles, simulation tools represent the best method to evaluate annual performance impacts in different climates. BEopt was used to evaluate the impact of different high performance wall system designs. Cost and wall design parameters were entered into BEopt so that net annual costs versus energy savings percentages could be charted and compared for each case.

\footnotetext{
${ }^{4}$ Draft Codes and Standards Enhancement report can be found at: http://energy.ca.gov/title24/2016standards/prerulemaking/documents/2014-0721_workshop/case_reports/2016_Title_24_Draft_CASE_Report-High_Performance_Walls_and_QII.pdf ${ }^{5}$ Conference calls and emails with Michael Gestwick and Ed Hancock, May 15 and $\overline{1} 6,2014$.
} 


\subsubsection{Climates Evaluated}

Because this project focused on hot dry western climates, the climates characterized in Table 2 were selected to evaluate the annual energy impact of the high performance wall systems relative to standard $2 \times 4$ construction. These locations provide a good cross-section of climates with both extremely hot and moderately hot summers, and climates with moderate and relatively cold winters.

Table 2. Climate Details of Locations Used in Analysis

\begin{tabular}{c|c|c|c|c}
\hline Location & $\begin{array}{c}\text { IECC } \\
\text { Climate Zone }\end{array}$ & $\begin{array}{c}\text { Annual } \\
\text { HDD }^{1}\end{array}$ & $\begin{array}{c}\text { Annual } \\
\text { CDD }^{1}\end{array}$ & $\begin{array}{c}\text { Heating/Cooling } \\
\left.\text { Design Temp ( }{ }^{\mathbf{0}} \mathbf{F}\right)^{\mathbf{2}, 3}\end{array}$ \\
\hline Phoenix & 2B & 923 & 4,626 & $41.6^{\circ} \mathrm{F} / 108.3^{\circ} \mathrm{F}$ \\
Sacramento & 3B & 2,425 & 1,390 & $33.7^{\circ} \mathrm{F} / 98.2^{\circ} \mathrm{F}$ \\
\hline Fresno & 3B & 2,266 & 2,097 & $33.7^{\circ} \mathrm{F} / 100.8^{\circ} \mathrm{F}$ \\
\hline Albuquerque & 4B & 3,994 & 1,370 & $21.6^{\circ} \mathrm{F} / 92.9^{\circ} \mathrm{F}$ \\
\hline
\end{tabular}

${ }^{1}$ Heating degree days and cooling degree days calculated with a base temperature of $65^{\circ} \mathrm{F}$.

${ }^{2}$ Temperatures based on $99 \%$ design conditions for heating and $1 \%$ for cooling.

${ }^{3}$ Degree days and design temperatures from the ASHRAE 2013 Fundamentals.

\subsubsection{Houses Evaluated}

Two representative houses were used to evaluate wall performance, a 2,100- $\mathrm{ft}^{2}$ one-story plan and a 2,700- $\mathrm{ft}^{2}$ two-story plan. The geometry and window areas correspond to the two prototype houses used by the CEC to develop and evaluate energy efficiency measures for the 2013 standards rulemaking process. All building characteristics and schedules follow the Building America Benchmark House Simulation Protocols (HSP), which are based on the 2009 IECC. Window orientations used are as listed in Table 3, and areas are $17.3 \%$ of floor area for the onestory and $20 \%$ of floor area for the two-story.

Table 3. Window Areas and Orientations

\begin{tabular}{c|c|c|}
\hline Orientation & $\begin{array}{c}\text { One-Story } \\
\left(\mathbf{f t}^{2}\right)\end{array}$ & $\begin{array}{c}\text { Two-Story } \\
\left(\mathbf{f t}^{2}\right)\end{array}$ \\
\hline Front (North) & 100 & 134 \\
\hline Left (East) & 56 & 68 \\
Back (South) & 151 & 270 \\
\hline Right (West) & 56 & 68 \\
\hline
\end{tabular}

\subsubsection{Wall Types Evaluated}

The base case wall against which other wall types were compared is consistent with the Building America Benchmark and with the 2009 IECC and consisted of the following:

- Studs and spacing: $2 \times 4,16$ in. o.c., $25 \%$ framing factor

- Insulation: R-13 batt, grade I insulation quality

- Exterior sheathing: Three-coat stucco, no OSB or rigid sheathing.

Stucco finish was assumed in the analysis because it is the most common exterior wall type found in new production homes in California and many of the drier regions of the western United 
States. Most production builders in California do not sheath homes with OSB; therefore, this analysis assumed from a cost perspective that no OSB was used on 16-in. o.c. walls.

Parametric evaluations of high performance wall types were completed as listed in Table 4. These types were not limited to the wall configurations applied by the participating builders so that other practical options could be identified. Because the study focuses on high performance walls, the grade I insulation quality was assumed for all cases.

Because stucco was assumed in the analysis, all high performance wall options with exterior foam sheathing assumed a one-coat stucco finish. Three-coat stucco was assumed for the doublestud wall, which included OSB but no exterior foam sheathing.

The framing factors used in the analysis ( $25 \%$ for 16 -in. o.c. walls and $22 \%$ for 24 -in. o.c. walls) are the same as prescribed in the House Simulation Protocols and used in Title 24 standards. ${ }^{6}$ These factors represent typical differences based on adjusting stud spacing and don't represent deeper reductions that are possible through the use of other high performance framing techniques. The sensitivity of wall performance to framing factor was not expected to be large given the minimum assumed 1-in. R-4 thermal break provided by the EPS exterior sheathing.

Table 4. Wall Types Evaluated

\begin{tabular}{|c|c|c|}
\hline Parameter & \# of Cases & Description \\
\hline Wall Type & 2 & $2 \times 6$ single, $2 \times 4$ double-stud framed* \\
\hline Stud Spacing & 2 & 16 in. ( $25 \%$ framing factor) and 24 in. ( $22 \%$ framing factor) \\
\hline $\begin{array}{l}\text { Cavity } \\
\text { Insulation }\end{array}$ & $3+1$ & $\begin{array}{c}\text { Single-stud walls: R-19 blown cellulose, R-21 batt, R-23 } \\
\text { blown-in blanket (fiberglass) } \\
\text { Double-stud wall: R-33 blown cellulose }\end{array}$ \\
\hline Sheathing & 3 & $\begin{array}{l}1 \text { in. R-4 EPS, } 1 \text { in. R-6 polyiso, } 2 \text { in. R-8 EPS } \\
\text { (single-stud only) }\end{array}$ \\
\hline Total Cases & 152 & 144 single-stud, 8 double-stud \\
\hline
\end{tabular}

*The framing factor for the double-stud wall was assumed to be $21.6 \%$ overall. Actual framing factors based on measurements of the Honda Smart Home were 26\% exterior, $17 \%$ interior, but only 3\% penetrating from the interior drywall to the exterior sheathing.

The double-stud wall modeled in this study was based on the recent implementation at the University of California Davis Honda house. Assembly performance was calculated using detailed field takeoffs to develop inputs for LBNL's Finite Element Simulator, THERM 7.2. This evaluation determined a wall composite R-value of 29.5, with a resultant U-value of 0.0339 $\mathrm{Btu} / \mathrm{h}-\mathrm{ft}-{ }^{\circ} \mathrm{F}$. Details of this analysis are included in Appendix B.

\subsubsection{Costs and Performance for High Performance Wall Systems}

BEopt modeling was completed to compare various wall design options relative to the base case, a $2 \times 4$ 16-in. o.c. wall with R-13 grade-I cavity insulation and three-coat stucco. To compare cost effectiveness of the various wall construction options, cost data were entered into BEopt. Incremental costs for exterior wall components and assemblies were developed from the following sources:

\footnotetext{
${ }^{6}$ Framing factors are from the ASHRAE Handbook - Fundamentals.
} 
- BEopt cost database

- CASE work by TRC, ${ }^{7}$ funded by the California IOUs

- Builder and contractor-supplied costs

- Materials pricing from suppliers and contractor outlets.

A base case wall cost of $\$ 7.85 \mathrm{ft}^{2}$ of exterior wall area was used. This reflects the total builder cost including materials, labor, overhead and profit for framing, insulation, and three-coat stucco. (Total exterior wall costs used were $\$ 14,300$, and $\$ 18,550$ for the $2,100-\mathrm{ft}^{2}$ single-story and $2,700-\mathrm{ft}^{2}$ two-story homes, respectively.) Total high performance wall system incremental costs relative to the base case wall are shown in Table 5. More cost details and assumptions are provided in Appendix C.

Table 5. High Performance Wall Incremental Costs (Over the $\$ 7.85 / \mathrm{ft}^{2}$ Base Case $2 \times 4 \mathrm{R}-13$ Wall)

\begin{tabular}{|c|c|c|c|}
\hline \multirow[t]{2}{*}{ Frame Wall } & \multirow{2}{*}{$\begin{array}{l}\text { Exterior } \\
\text { Sheathing }\end{array}$} & \multicolumn{2}{|c|}{$\begin{array}{c}\text { Total Assembly } \\
\text { Incremental Cost }\left(\text { per } \mathrm{ft}^{2}\right)\end{array}$} \\
\hline & & 16 in. o.c. & 24 in. o.c.* \\
\hline \multirow{3}{*}{$\begin{array}{c}2 \times 6 \text { Wall, R-19 Blown } \\
\text { Cellulose, One-Coat Stucco }\end{array}$} & 1 in. R-4 EPS & $\$ 0.13$ & $\$ 0.33$ \\
\hline & 1 in. R-6 Polyiso & $\$ 0.38$ & $\$ 0.58$ \\
\hline & 2 in. R-8 EPS & $\$ 0.61$ & $\$ 0.81$ \\
\hline \multirow{3}{*}{$\begin{array}{c}2 \times 6 \text { Wall, R-21 Fiberglass } \\
\text { Batt, One-Coat Stucco }\end{array}$} & 1 in. R-4 EPS & $\$ 0.19$ & $\$ 0.40$ \\
\hline & 1 in. R-6 Polyiso & $\$ 0.45$ & $\$ 0.65$ \\
\hline & 2 in. R-8 EPS & $\$ 0.67$ & $\$ 0.88$ \\
\hline \multirow{3}{*}{$\begin{array}{l}2 \times 6 \text { Wall, R-23 Blown } \\
\text { Fiberglass, One-Coat Stucco }\end{array}$} & 1 in. R-4 EPS & $\$ 0.47$ & $\$ 0.68$ \\
\hline & 1 in. R-6 Polyiso & $\$ 0.73$ & $\$ 0.93$ \\
\hline & 2 in. R-8 EPS & $\$ 0.95$ & $\$ 1.16$ \\
\hline $\begin{array}{c}\text { Double-Stud Wall, R-33, } \\
\text { One-Coat Stucco }\end{array}$ & OSB & $\mathrm{n} / \mathrm{a}$ & $\$ 3.07$ \\
\hline
\end{tabular}

*All 24 in. o.c. cases include full OSB sheathing for structural support.

Cost differences between 16-in. and 24-in. o.c. framing include a cost savings for less framing material and labor ${ }^{8}$ and a cost adder for full wrap OSB sheathing. Because of its wider framing spans, OSB sheathing is strongly recommended by structural engineer Tim Sloan for 24-in. o.c. construction for improved structural support of the stucco.

Base case and all high performance walls were assumed to be grade I installation with no insulation voids or compression. This is the assumption for the Building America Benchmark and an IECC prescriptive wall. It is also assumed that any high performance wall, to perform as designed, shall be inspected to meet grade I quality. Clearly, insulation installation quality is a factor that requires vigilance from the builder, insulator, and HERS inspector because it will impact wall thermal performance and overall wall durability. Table 6 provides a comparison of

\footnotetext{
${ }^{7}$ The engineering firm TRC was responsible for developing the CASE report on high performance walls and compiled cost data that were used to determine the cost effectiveness of various advanced wall system components. ${ }^{8}$ Reduced labor for framing may be expected once this technology is mature, but may not be immediately realized as the market gains familiarity with these practices.
} 
the U-values of the various wall system configurations using the grade I insulation quality assumption.

Interviews with the PG\&E project participating builders revealed that the actual incremental costs for high performance wall designs were often much higher than the values used in our parametric analysis. For example, homebuilder Wathen Castanos reported incremental costs for its $2 \times 6$, 16-in. o.c., R-23 + 1-in. EPS high performance wall of about $\$ 1.30 / \mathrm{ft}^{2}$ of exterior wall area (relative to $2 \times 4,16$-in. oc, R-15 +1 -in. EPS base wall), but noted contractors tend to bid high when change orders are issued, as was the case in this project where only one home in the subdivision was modified. In a competitive bidding environment, this builder thinks the incremental labor cost would be closer to $\$ 0.10 / \mathrm{ft}^{2}$ instead of the $\$ 0.58 / \mathrm{ft}^{2}$ he received from his contractor. ${ }^{9}$ Costs provided by homebuilder GJ Gardner for its $2 \times 6$ 24-in. o.c. R-19+1-in. EPS wall suggest lower incremental labor costs $\left(\sim \$ .092 / \mathrm{ft}^{2}\right.$ relative to $2 \times 4,16$-in. o.c., $\mathrm{R}-13+1$-in. EPS) than observed by Wathen Castanos, possibly based on the fact that framing bids were based on a construction phase representing 155 homes. Total "per $\mathrm{ft}^{2}$ " incremental framing costs of $\$ 0.44 / \mathrm{ft}^{2}$ for GJ Gardner are slightly higher than the $\$ 0.36 / \mathrm{ft}^{2}$ assumed in the parametric study (\$2.20 versus $\$ 1.84$ ) suggesting that the assumed mature cost level is not unreasonable.

Table 6. High Performance Wall Assembly U-Value

\begin{tabular}{|c|c|c|c|}
\hline \multirow[t]{2}{*}{ Frame Wall } & \multirow{2}{*}{$\begin{array}{l}\text { Exterior } \\
\text { Sheathing }\end{array}$} & \multicolumn{2}{|c|}{$\begin{array}{c}\text { Total Assembly U-Value } \\
\left.\text { (Btu/h-ft }{ }^{2}\right)\end{array}$} \\
\hline & & 16-in. o.c. & 24-in. o.c.* \\
\hline \multirow{3}{*}{$\begin{array}{c}2 \times 6 \text { Wall, R-19 Blown } \\
\text { Cellulose, One-Coat Stucco }\end{array}$} & 1 in. R-4 EPS & 0.054 & 0.053 \\
\hline & 1 in. R-6 Polyiso & 0.048 & 0.046 \\
\hline & 2 in. R-8 EPS & 0.043 & 0.042 \\
\hline \multirow{3}{*}{$\begin{array}{c}2 \times 6 \text { Wall, R-21 Fiberglass } \\
\text { Batt, One-Coat Stucco }\end{array}$} & 1 in. R-4 EPS & 0.051 & 0.050 \\
\hline & 1 in. R-6 Polyiso & 0.046 & 0.044 \\
\hline & 2 in. R-8 EPS & 0.041 & 0.040 \\
\hline \multirow{3}{*}{$\begin{array}{l}2 \times 6 \text { Wall, R-23 Blown } \\
\text { Fiberglass, One-Coat Stucco }\end{array}$} & 1 in. R-4 EPS & 0.049 & 0.048 \\
\hline & 1 in. R-6 Polyiso & 0.044 & 0.043 \\
\hline & 2 in. R-8 EPS & 0.040 & 0.039 \\
\hline $\begin{array}{c}\text { Double-Stud Wall, R-33, } \\
\text { One-Coat Stucco }\end{array}$ & OSB & $\mathrm{n} / \mathrm{a}$ & 0.034 \\
\hline
\end{tabular}

*All 24-in. o.c. cases include full OSB sheathing for structural support.

\footnotetext{
${ }^{9}$ In the competitive production home environment subcontractors typically use change orders as means of recovering losses or increasing revenue.
} 


\section{Results}

\subsection{Field Observations}

\subsubsection{Measured Framing Factors}

A very detailed accounting of all wood penetrating the wall cavity was completed on eight different homes to determine the framing factor for typical base case houses. All except one of these base case homes used $2 \times 4$ framing. Total wall framing factors, including headers, plates, blocking, and other associated framing penetrating the wall cavity, varied between $25.7 \%-35.5 \%$ of net wall area (after window and door area removed). The single builder that used $2 \times 6$ framing had the lowest stud count per foot of wall but the highest overall framing factor. A primary factor in the high overall framing factor in this $2 \times 6$ framed house related to the unique window framing detail shown in Figure 1 . The $2 \times 4$ framing treatment around all windows was included to achieve an architectural effect that is apparent from outside.

Framing factors were also obtained from the four models built with high performance wall systems. All were of $2 \times 6$ construction with R-4 exterior sheathing. Overall framing factors ranged from $21.3 \%$ to $21.4 \%$ for the two houses using 24 -in. o.c. framing and from $24 \%$ to $25.7 \%$ for the two houses using 16 -in. o.c. framing. More detailed framing factor information by site is provided in Appendix D.

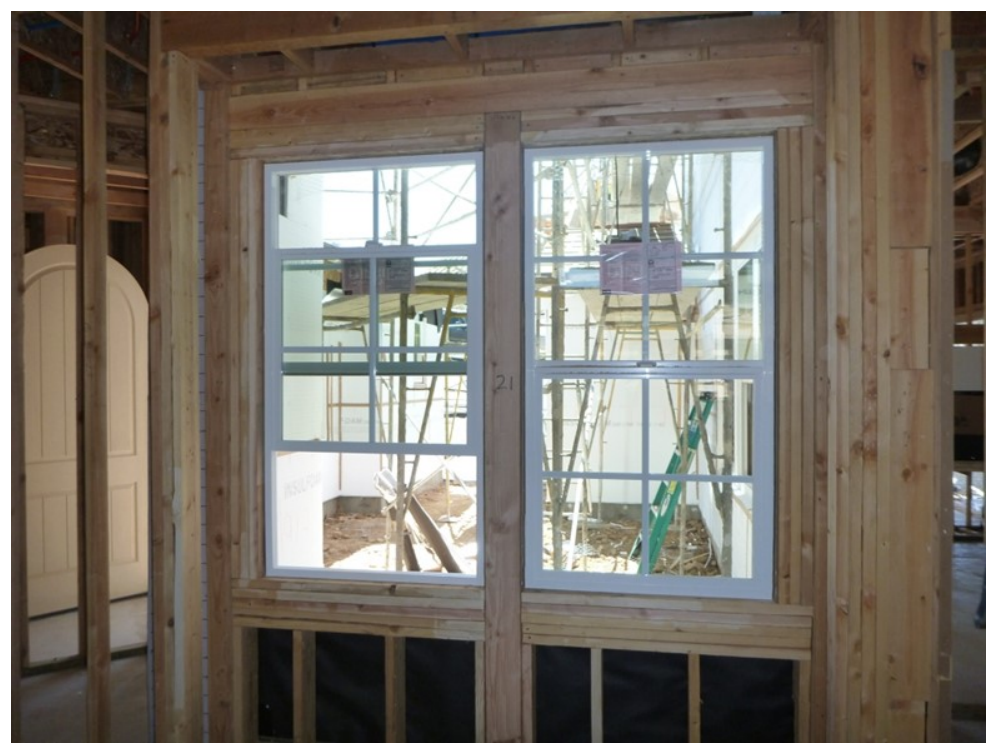

Figure 1. Example of excessive framing at windows (recessed in $2 \times 6$ wall)

\subsubsection{High Performance Wall System Framing Methods}

Two of the builders, Wathen Castanos and Northwest Homes, used 16-in. o.c. framing and blown-in-blanket (BIB) insulation. Wathen Castanos cited wind load concerns expressed by its structural engineer and resistance from its framing contractor in modifying framing practice as reasons for not implementing 24-in. o.c. framing. Larger builders work with framing subcontractors who contract on a piece work basis. Framer bids are therefore for labor only and based on either the floor area or the wall area, with the builders paying directly for the lumber. This approach isolates the builders from the framing process, making control of framing 
techniques more difficult. Nevertheless, Wathen Castanos was able to employ multiple techniques to reduce thermal bridging, as illustrated in Figure 2.

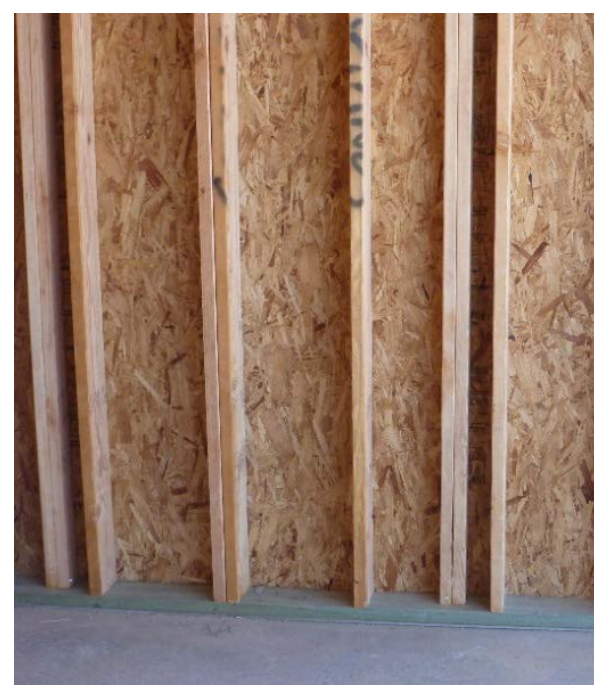

Use of $2 \times 4$ studs to minimize thermal bridging

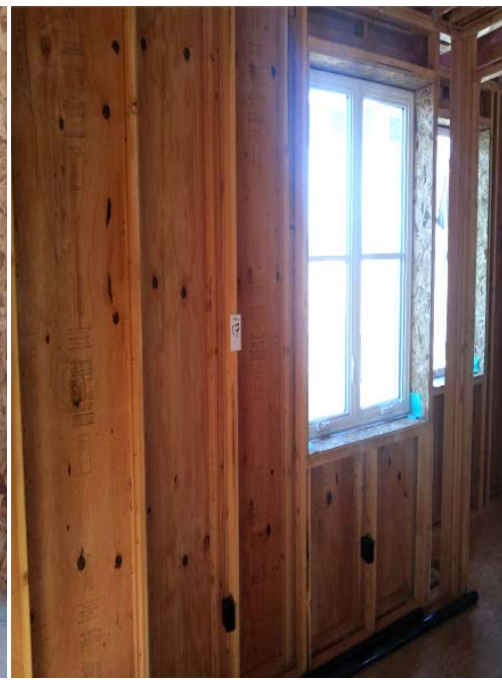

Truss-joist header

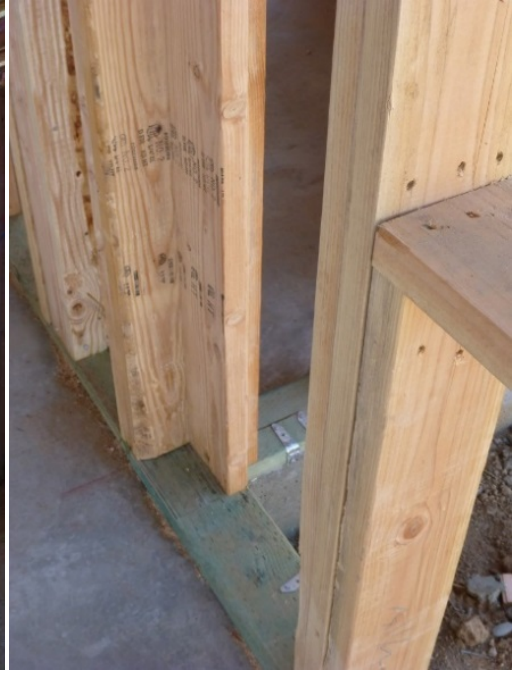

Intersecting exterior wall

Figure 2. Wathen Castanos' high performance framing techniques

Northwest Homes used a similar approach to high performance wall framing as Wathen Castanos, including standard double top plates, truss-joist headers, and the same three-stud corner detail ("a" instead of " $b$ " in Figure 3). While the three-stud corner does not allow for a layer of insulation as thick as the three-stud corner, it provides a firm nailing base for drywall and eliminates the need for drywall clips. ${ }^{10}$ Both also used flat studs rather than ladder framing at intersecting walls as shown in Figure 3c.

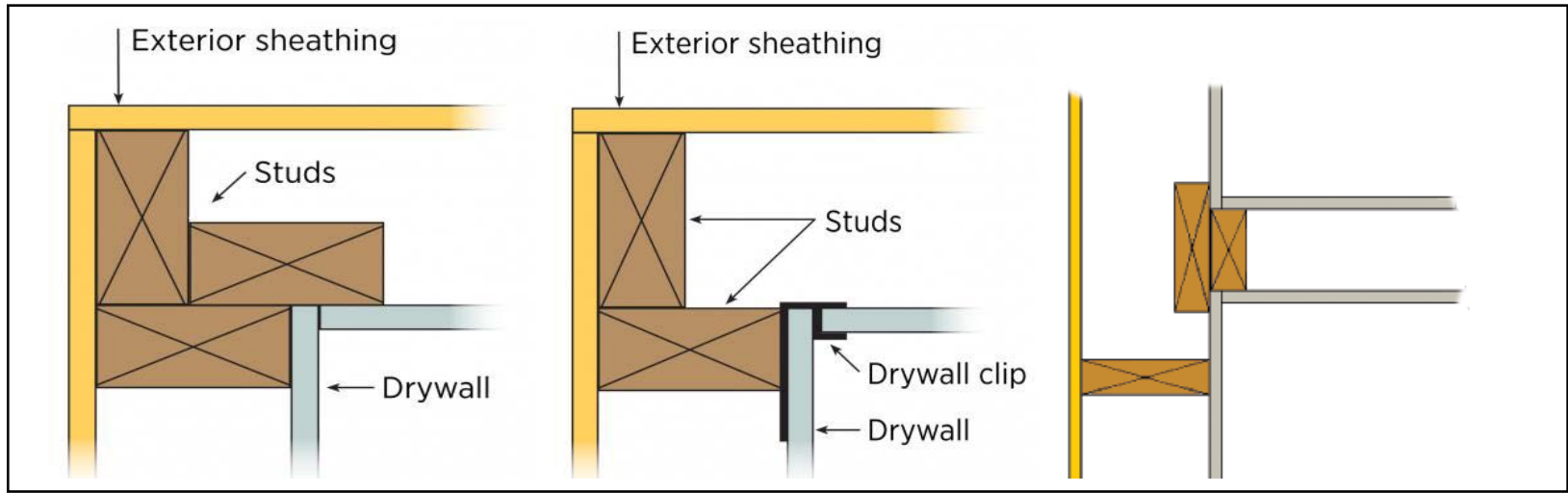

(a) 3-stud corner

(b) 2-stud corner

(c) Intersecting wall

Figure 3. Outside corner and intersecting wall details

\footnotetext{
${ }^{10}$ Based on feedback from structural engineer Tim Sloan, for the two-stud corner there is about an even cost tradeoff between lumber savings and added costs for drywall clips, and drywall contractors are resistant to the latter.
} 
Northwest Homes also used the BIB insulating system to achieve R-23 cavity insulation levels in the framed wall cavity, in addition to the R-4 exterior EPS insulation. The builder indicated that for the last 6 or 7 years, it has exclusively used the BIB system because it strongly believes that delivering consistent wall cavity performance using fiberglass batts is challenging. The $\$ 500$ to $\$ 700$ cost premium for the BIB system on a typical $2,000 \pm \mathrm{ft}^{2}$ house ${ }^{11}$ is an expenditure that the builder feels is worth the investment. Figure 4 shows the insulated exterior wall, with the left photo depicting a batt insulated wall to the garage to the right of the BIB-insulated wall.

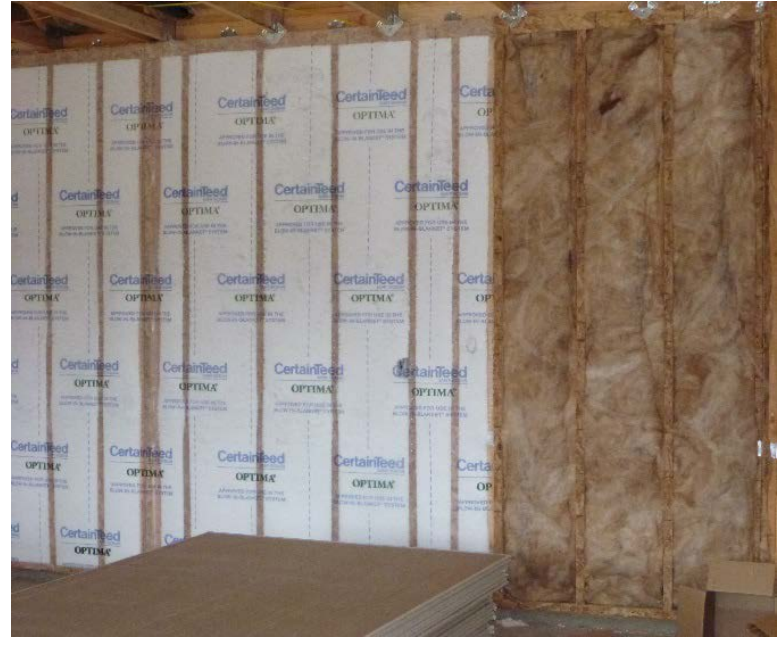

Conservative use of studs and high quality insulation

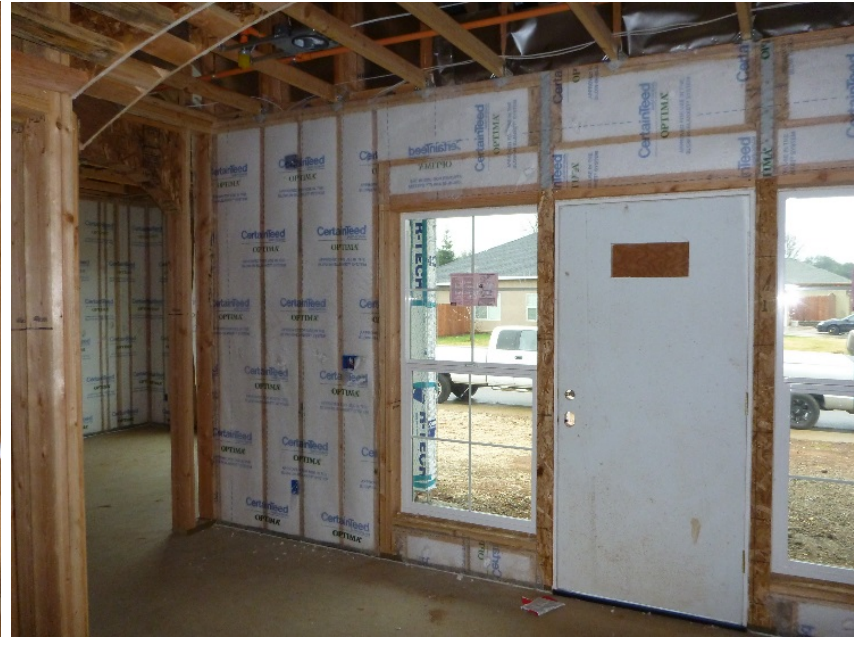

Insulated truss-joist headers

Figure 4. Northwest Homes framing examples

Builder GJ Gardner decided to implement 24-in. o.c. framing at not just two PG\&E test homes participating in the walls and ducts program, but at a total of 155 homes to be built in two phases in its project in Sanger, California. Ambitiously implementing these strategies on a larger scale, rather than a one-off approach, allows the builder and subcontractors to become comfortable with the implementation through repetition and refinement. One of the very early homes with 24in. o.c. framing is shown in Figure 5 with solid results in reducing the wood content in exterior and interior walls. Exterior 7/16-in. OSB sheathing was used for several reasons:

- To provide added rigidity to the exterior wall.

- To provide adequate support for the one coat stucco system to eliminate waviness.

- To provide additional wall resistance to air infiltration.

${ }^{11} \sim 1,800 \mathrm{ft}^{2}$ of exterior wall area 


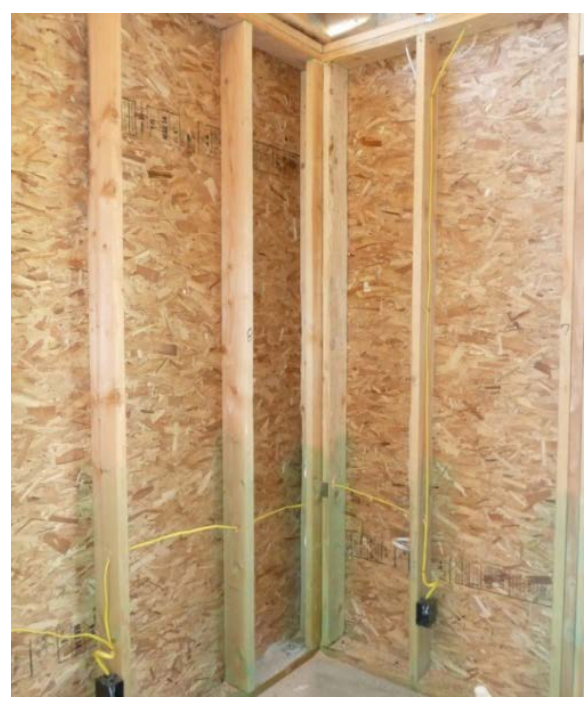

Intersecting exterior wall

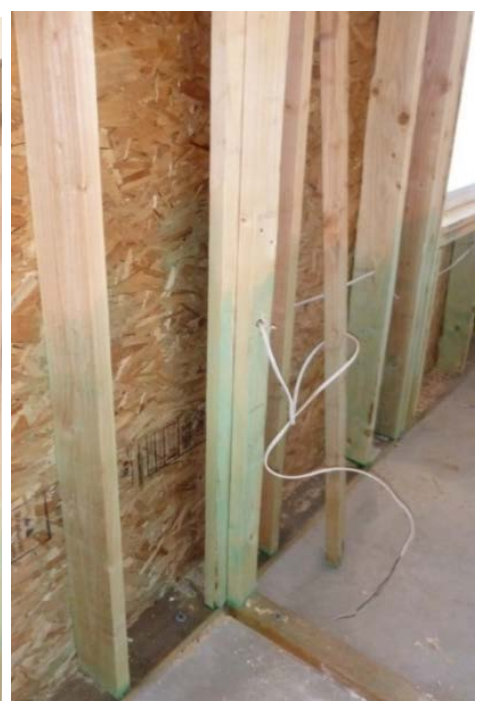

Three-stud outside corner

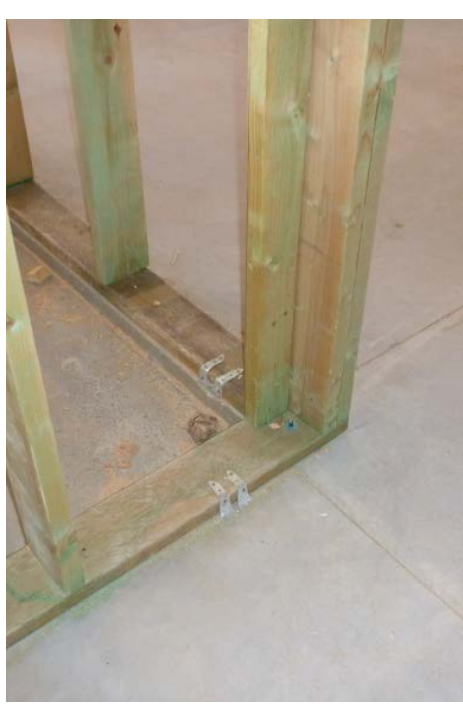

Three-stud inside corner

Figure 5. GJ Gardner's wall details-24 in. o.c. framing and double top plates

\subsubsection{General Observations and Risk Factors}

Project team members Rick Chitwood and Tim Sloan contributed their thorough knowledge about California framing practices, including barriers, opportunities, and future directions. Rick Chitwood, who served as the project's lead field engineer, has more than 25 years of experience inspecting and testing hundreds of homes throughout California, as well as many years as a home performance contractor and builder of homes that are far ahead of energy codes and demonstrate exceptional performance, as verified by low energy use. His perceptions are summarized in the following two paragraphs.

Over the past decade, the state of residential building envelopes has improved as insulation quality standards have tightened under Title 24, and draft-stopping practices have eliminated most of the major leakage paths in the ceiling plane as well as in walls. Although there is increasing attention on air sealing, there is a critical need for a better understanding of overall building science principles so that more time can be focused on the areas that matter most. The need for quality control mechanisms and feedback from testing (e.g., identifying leakage paths with an infrared camera while the home is depressurized with a blower door) is critical in educating contractors on the weaknesses of their construction practices and to help them identify where their effort should be expended.

For framers, there is room to improve framing techniques that make it possible for insulation crews to do quality installations. This is especially problematic for batt insulation, as irregular cavities lead to the necessity to cut and fit batts, which requires more time and compromises quality. The code compliance option for QII in California has helped to improve the average quality of wall insulation workmanship, although the nature of the relationship between the builder and the HERS rater can still lead to lower quality work. Builders hold HERS raters to the same standard as subcontractors in terms of not delaying construction schedules or impacting costs. HERS raters who flag QII failures and slow the construction process can lose favor with 
the builders who hire them, and builders are not called upon to correct defects as much as they should be. Although batt insulation is by far the predominant means of insulating walls in California production homes, Chitwood feels that raising the standard of batt insulation to a consistent level equal to that required by QII would increase wall insulation costs to close to what alternative strategies such as BIB insulation currently costs. Builder partner Fred Bergstrom of Northwest Homes indicated that to ensure a high quality wall insulation job he insists on the BIB technique, realizing that the cost will be $\$ 500-\$ 700$ or more higher for a typical sized house. $^{12}$

Structural engineer Tim Sloan's experience in the California market and interest in advanced framing over the past 10 years of working with production builders has informed his perception of how high performance wall designs can be practically implemented. Sloan is not a believer in the single top plate and aligned truss concept. Although it "looks good in pictures," a lot of realworld complications arise when working with production builder architects and in designing to a 2-ft layout. This approach impacts the alignment of interior walls, lighting layout, and window locations, because architects want to center windows in rooms and not be constrained by a 2-ft module. Most of the production home builders employ large architectural firms, whose design focus centers around what the market wants as conveyed to them by builder marketing departments. One builder Sloan had worked with approximately 4 years ago was intent on implementing 24-in. o.c. framing on a project, but during the design review stage the builder's team decided too many alignment issues complicated the construction process and they therefore decided to drop the approach. Sloan feels that for high performance framing to "really take off, the single top plate shouldn't be pushed very hard because it only makes sense for people inside of academia to present in computer models and in PowerPoint presentations, but that don't actually have to build anything." In the near term, Sloan thinks advanced framing, particularly 24-in. wall and truss layouts, will likely be limited to smaller local builders and architects who are more inclined to be innovative.

In terms of mapping out a transition path for California builders to move to high performance framing principles, Sloan visualizes a two-step progression beginning with implementation of QII procedures, two-stud corners, ladder framing, and raised heel roof trusses. There are no significant barriers to achieving this. The next step, the transition to 24-in. o.c. framing and use of drywall clips, will be more challenging because there is currently significant resistance to their adoption. Part of the resistance to 24-in. framing is that the anticipated lumber cost savings are often less than builders expect. Given that 24-in. o.c. framing must be wrapped with OSB sheathing to keep walls straight and provide a solid base for stucco, the builder may ask "Why am I doing this?"

Sloan expressed that most mainstream production builders may be slow to embrace concepts related to advanced framing because of perceived risk. As a group, builders have liability concerns about being first on the market with any new technology or measure. They must also deal with the marketing perception that the high performance wall they are offering the buyer appears to be less robust. ${ }^{13}$ His experiences suggest that bigger builders are primarily driven by

\footnotetext{
${ }^{12}$ This is consistent with the $\$ 0.39 / \mathrm{ft}^{2}$ incremental cost (per $\mathrm{ft}^{2}$ of floor area) identified in the Earth Advantage survey.

${ }^{13}$ Two of the builders participating in the PG\&E project expressed a similar sentiment in that they feel that their buyers perceive a wall with less wood as being a "cheaper wall."
} 
the bottom line ("will it sell faster or make me more money..."), while smaller local builders are nimbler and more likely to see various advanced construction strategies as a niche feature that they can tailor to their overall marketing effort. The nature of how larger builders tend to operate is that the construction team, purchasing department, warranty department, and sales/marketing team are all operating independently, creating somewhat of an operational disconnect. Low first costs desired by the purchasing team may mean more problems for others (such as warranty issues), but these issues are not their primary concern. His experience is that in the beginning of a market upturn, the purchasing departments tend to be driving things solely on the basis of low first cost. As the market improves and home prices rise, the dynamic shifts and other departments start to gain more influence and control over decision making. As the market cycle changes and sales start to fall off, the internal dynamics shift again.

One of ARBI's builder partners indicated that competing economic pressures in the current market are driving builders to reconsider their pursuit of energy efficiency initiatives, despite the state's ambitious goal of achieving ZNE new homes by 2020 . These pressures include reduced utility incentives through the statewide CAHP incentive program and tightening Title 24 energy compliance requirements (and therefore construction costs) to meet CAHP program performance levels. A vanishing pool of inexpensive lots acquired during the 2008-2009 market crash and pressures from the builder's sales team to hold the line on pricing are also driving this builder to back down from its market strategy of offering homes that are $30 \%$ above the Title 24 code. This tension between the construction team and the sales arm adds to the challenges of promoting energy-efficient technologies that may not be uniformly desired by homebuyers and that are more expensive to include.

\subsection{BEopt Modeling Results}

The goal of modeling was to identify the least-cost wall design options relative to life cycle annualized costs that include initial capital costs as well as utility bill costs, and quantify the expected range of energy savings for the hot-dry climates studied. Figure 6 and Figure 7 present annualized energy cost ( $\mathrm{Y}$-axis) relative to source energy savings (X-axis) for the 19 high performance wall options for the 2,100- $\mathrm{ft}^{2}$ and $2,700-\mathrm{ft}^{2}$ prototypes, respectively. Each graph has four performance curves that represent the least-cost curve for each of the four locations evaluated. The leftmost point on each curve indicates the base case condition ${ }^{14}$ with zero source energy savings. On the far right, the option that offers maximum energy savings for all the scenarios is the double-stud wall case. While this wall has a lower annualized cost than the base case, it's also higher than the other single-stud high performance wall options. All of the singlestud wall improved cases sit at approximately the same annualized cost point, but with projected savings that vary by $1 \%-2 \%$. The $2,100-\mathrm{ft}^{2}$ prototype demonstrates projected source energy savings of 6.5-10.5 MMBtu/year, while the 2,700- $\mathrm{ft}^{2}$ prototype shows projected savings of 10 15.5 MMBtu/year.

Figure 8 presents savings results as a percentage of total heating, ventilation, and air conditioning (HVAC) source energy for each climate, and provides average savings for the cases with both 1 in. and 2 in. of exterior foam combined with different wall framing types (16 in. o.c., 24 in. o.c., and double stud). Representing the results in this format shows both the magnitude of potential savings in different climates and the sensitivity of the savings to various parameters. Projected

\footnotetext{
${ }^{14}$ The 2009 IECC wall provides a performance standard lower than the Title 24 prescriptive wall for the Sacramento and Fresno locations $(2 \times 4,16$-in. o.c., R-15, with R-4 exterior insulation).
} 
savings of the high performance wall system alternatives range from $12 \%-16 \%$ in the hot Phoenix climate to $15 \%-20 \%$ in the cooler Sacramento climate (see Table 2 for a degree day and design temperature comparison). Two-story homes are projected to have consistently higher savings impacts (adding 1 to 3 percentage points), a logical outcome because walls in two-story homes represent a larger fraction of the envelope load than in one-story homes. For builders interested in building with only 1 in. of exterior foam, the average savings are reduced by 1 or 2 percentage points versus the 2-in. case. A similar 1- to 2-point performance sensitivity is projected for the difference between 16- and 24-in. o.c. framing.

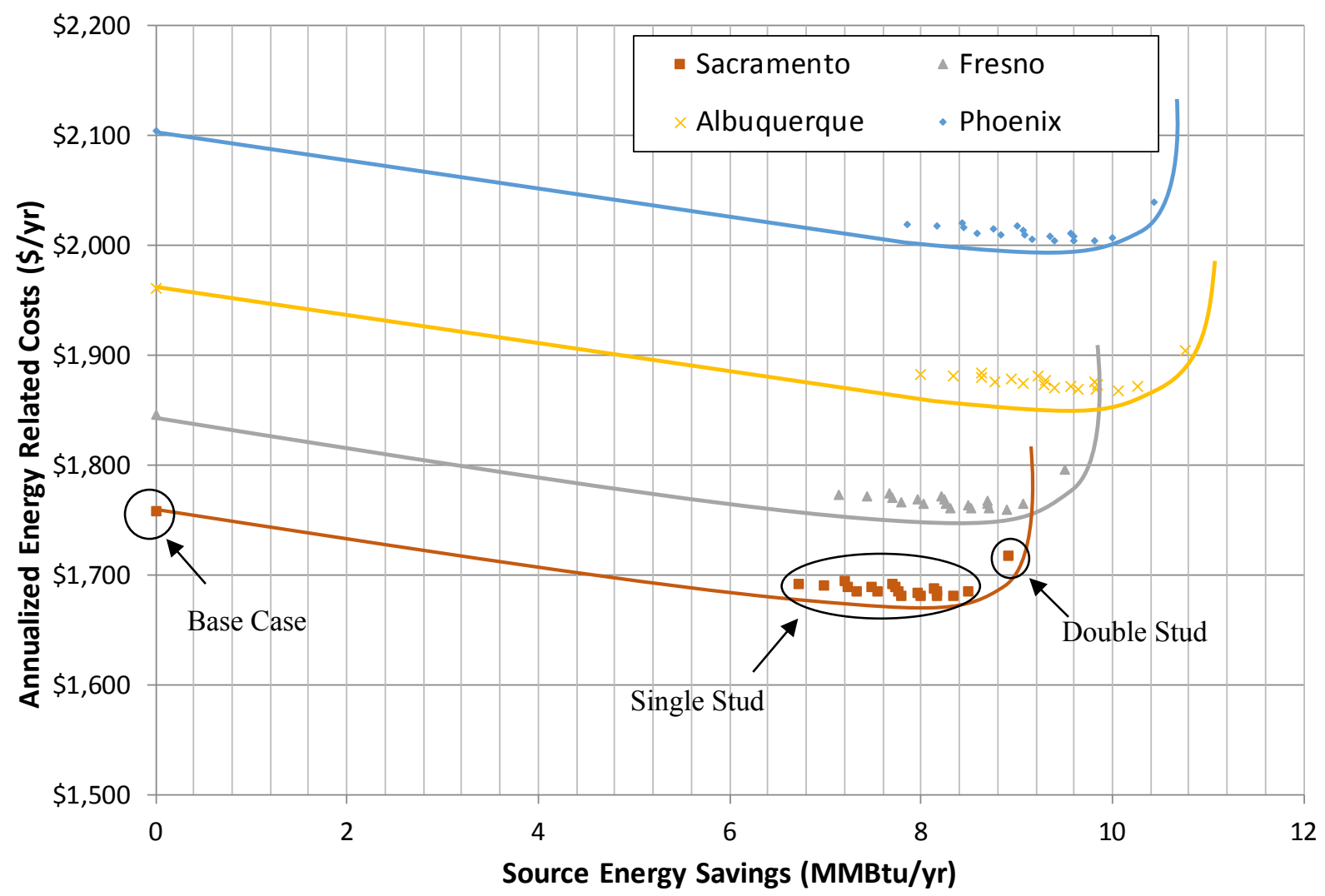

Figure 6. Least-cost curve for alternative wall systems $\left(2,100-\mathrm{ft}^{2}\right.$ prototype $)$ 


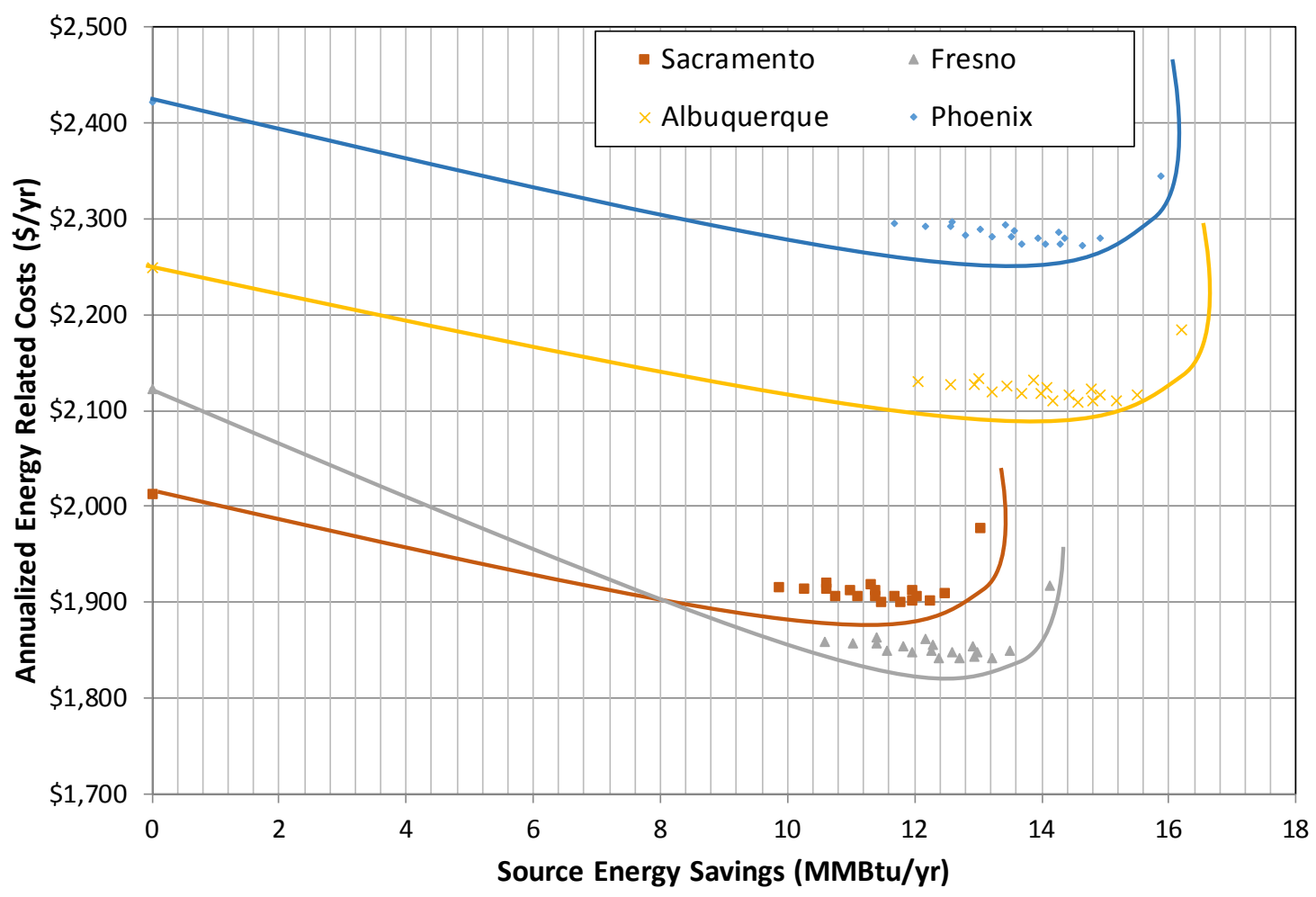

Figure 7. Least-cost curve for alternative wall systems $\left(2,700-\mathrm{ft}^{2}\right.$ prototype $)$

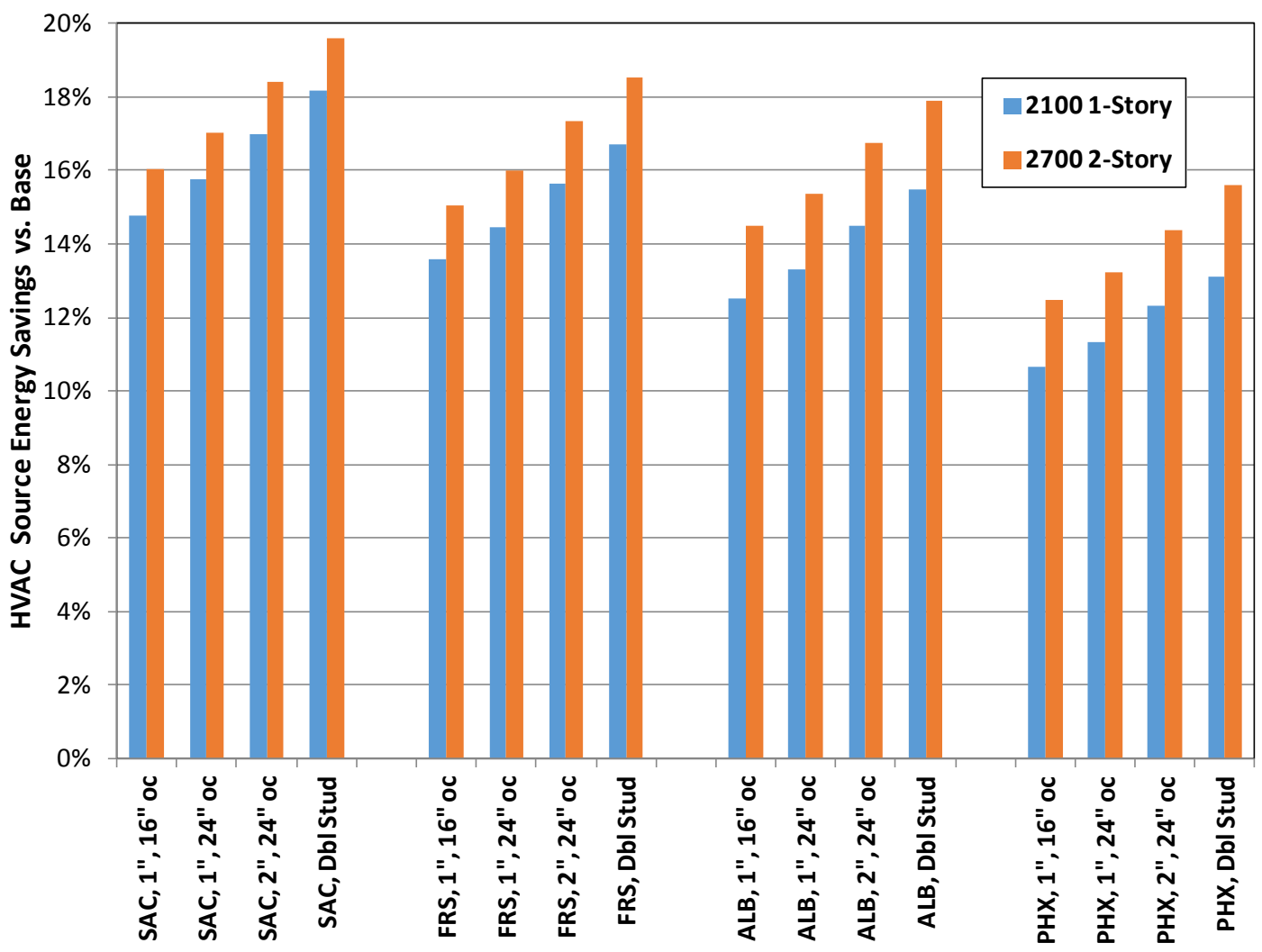

Figure 8. Aggregated HVAC source energy savings by climate and wall configuration 


\subsection{Tradeoffs}

The cost of high performance walls can be traded off against other measures that may yield higher returns, but the long-term persistence of high performance wall savings, the lost opportunity if they are not used, and the savings in HVAC system initial costs and operating costs makes them stand alone as a valuable energy efficiency measure to be included as part of a new zero energy ready home.

From a marketing perspective, photovoltaic (PV) systems are increasingly seen by California builders as a visible badge of their commitment to energy efficiency, and many builders are offering them under a third-party lease arrangement that costs the builder nothing. The CEC is also considering allowing PV systems to be used as code compliance "off-ramps" for measures that are less popular with builders, possibly including high performance walls (for 2016). To illustrate the relative cost effectiveness of PV versus high performance walls, a single BEopt analysis was completed for the $2,100-\mathrm{ft}^{2}$ prototype in the Sacramento climate. A net cost (after tax credits and other incentives) of $\$ 3.50 / \mathrm{W}$ was assumed for PV in this analysis.

Figure 9 plots the base case 2009 IECC cost point (on the Y-axis at zero savings), the single and double-stud wall data, and three data points for PV sizings of 2, 3, and $6 \mathrm{~kW}$. The graph provides context for the projected energy savings for high performance walls and conveys how the builder may perceive these two measures from a marketing perspective. Although the high performance wall alternative represents a cost-effective efficiency solution, the builder must weigh the first cost impacts and other market factors in its tradeoff analysis. In the example shown, the 2-kW PV system has an annualized cost $\sim \$ 60 /$ year higher than the double-stud wall case.

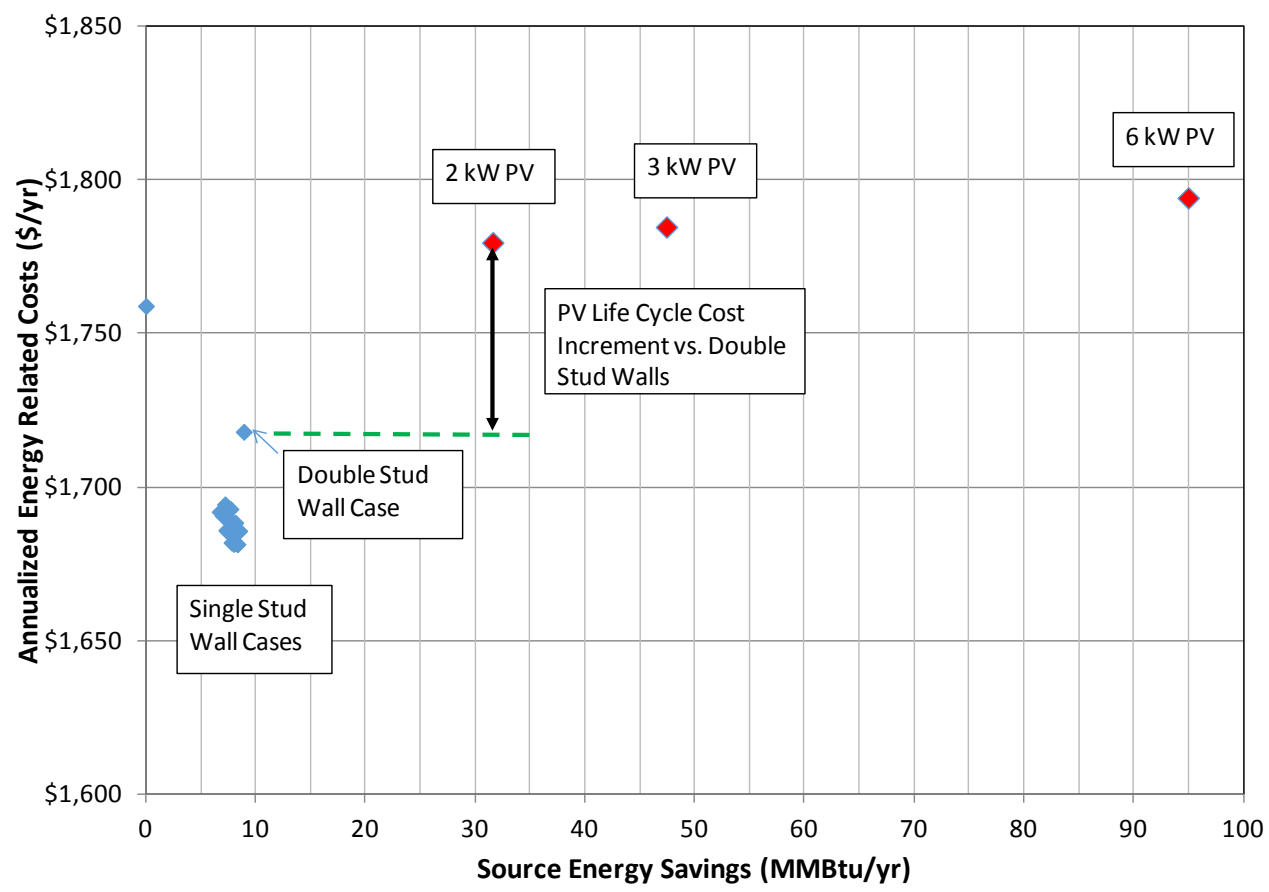

Figure 9. Annualized cost comparison of PV system to high performance walls 


\subsection{Nonenergy Benefits}

Several potential nonenergy benefits are associated with the practice of high performance wall framing:

- Durability: Builders who take the time to learn high performance framing techniques are also likely to learn how to build walls that are immune to moisture damage.

- Construction quality: An increased focus on construction quality could have other positive consequences such as making better accommodations for wall insulation installation, resulting in potential labor cost savings as well as improved thermal integrity.

- Noise reduction: Thicker, better insulated walls provide better sound insulation.

- Resource conservation: Where the number of board feet of solid lumber (i.e., for studs and headers) can be reduced, advanced framing conserves timber resources; if 24-in. o.c. framing necessitates the addition of OSB sheathing, the source material for OSB is a smaller, fast-growing species such as Aspen, Southern yellow pine, or poplar.

- Structural benefits: OSB sheathing used with 24-in. o.c. framing can provide additional structural value for improved resistance to wind and seismic loads. 


\section{Conclusions and Recommendations}

BEopt results for the climates modeled suggest all high performance wall types evaluated are cost effective relative to the 2009 IECC benchmark wall. The double-stud wall was found to be the least cost-effective option in all cases in these climates, primarily because of the high costs (cost increment more than three times higher than other high performance walls) and low heating loads. Small variations in source energy savings are projected among the various $2 \times 6$ wall types, although annualized costs for all $2 \times 6$ wall systems are approximately equal. This gives builders greater flexibility in applying acceptable strategies to their designs without concern over "lost savings." Even in the mild winter climates modeled for this study, the high performance walls were found to be a considerably better investment than PV because the measure is permanent.

The market for high performance walls needs to be developed from the ground up. California is a natural starting point for bringing this concept to mainstream production builders because of its aggressive Title 24 code, loading order of efficiency first, and use of public goods funds to support initial transformation efforts through incentive programs such as CAHP. Starting with architects and structural engineers, the market needs to be developed with increased training for architects, structural engineers, framing subcontractors, and insulators. Focus should be on high performance wall construction methods and proper construction details related to moisture control, minimizing wall wood content, and providing for effective air sealing. Builders who gain increasing experience with the measure should see, over time, other ancillary benefits such as reduced callbacks, and potentially reduced HVAC bids as contractors recognize the benefit of improved and consistent envelope performance. Potential HVAC benefits include equipment downsizing and more compact duct systems as the need for room exterior registers and multiple registers (in the great room for example), become unnecessary.

Builder perceptions suggest that homebuyers are not aware of this as a measure, and they are not particularly motivated by it, likely because of benign winter climates. Two builders suggest that they have received feedback from homebuyers who perceive that a 24-in. o.c. framing construction wall looks cheaper. Because this measure isn't necessarily appealing for homebuyers, building standards are arguably the proper vehicle for raising the bar and transforming the market. The lack of homebuyer awareness of the benefits of high performance walls often makes this measure a challenge for the sales team. With competition from other builders, each builder must make a strategic decision on what amenities the market values and how they can gain a competitive advantage. This leads to some tensions within the builder's management team as different priorities compete for inclusion in the builder construction package. Again, potential energy standards requiring the measure as a prescriptive requirement would eliminate this issue as a barrier.

Costs for high performance framing are potentially lower than estimated here once framers and drywallers have been retrained. This was made evident in the SCE ZNE project where the framer at first balked at the prospect of implementing 24-in. o.c. framing, but with close coordination during construction, left the project feeling good about the new approach. One builder participating in the project found fairly low incremental costs for $2 \times 6,24$-in. o.c. implementation, because the framer had some familiarity with the approach, and was bidding on $150+$ homes. 
Insulation installation quality, although improved over the past $10-15$ years, will continue to be a problem as long as the HERS rater is directly employed by the builder. Similar to other subcontractors, the HERS rater is held to schedule and price as the two key performance metrics.

Recommendations from this project included:

- The experiences of early implementers of high performance wall systems need to be captured in case studies that document the design and construction process, costs, and builder experiences. Improved documentation of costs will help the industry hone in on preferred methods.

- Detailed construction documents and framing plans, as well as onsite training of framers, insulators, and drywall crews is needed as the construction team makes the initial transition to high performance wall designs.

- Support training for architects and the builder's purchasing, marketing, and sales teams. Encourage a builder business structure that facilitates more interaction between forward planners, marketing and sales, purchasing, and construction teams. 


\section{References}

DeRenzis, A.; Kochkin, V. (2013). High-R Walls for New Construction Structural Performance: Wind Pressure Testing. Golden, CO: National Renewable Energy Laboratory. DOE/GO 102013-3627.

http://apps1.eere.energy.gov/buildings/publications/pdfs/building_america/highr_walls_wind_pr essure_test_.pdf.

DeRenzis, A.; Kochkin, V.; Wiehagen, J. (2013). High-R Walls for New Construction Structural Performance: Integrated Rim Header Testing. Golden, CO: National Renewable Energy Laboratory. DOE/GO -102013-3595.

http://apps 1.eere.energy.go.v/buildings/publications/pdfs/building_america/highr_walls_new_co nstruction.pdf

Earth Advantage. (2013). Cost Premiums for Select High Performance Building Components. Portland, OR. Accessed January

2015: https://www.earthadvantage.org/assets/documents/CostPremiumsForSelectHighPerforman ceBuildings-FINAL-140203.pdf.

Holladay, M. (2010). "The Pros and Cons of Advanced Framing." Accessed January 2015: http://www.greenbuildingadvisor.com/blogs/dept/musings/pros-and-cons-advancedframing.

Lstiburek, J. (2004). Vapor Barriers and Wall Design. Research Report-0410. Somerville, MA: Building Science Corporation.

Lstiburek, J. (2008). Builders Guide to Structural Insulated Panels (SIPs) for All Climates. Building Science Press. Building Science Corporation. Somerville, MA.

Lstiburek, J.; Grin, A. (2010). Building America Special Research Project: Deployment of Advanced Framing at the Community Scale. Research Report - 1004. Somerville, MA: Building Science Corporation.

RECS (2013). Table CE3.1. Accessed January

2015: http://www.eia.gov/consumption/residential/data/2009/index.cfm?view=consumption\#end -use.

SCE (2014). Zero Net Energy New Home. Report No. ET11SCE2030. Emerging Products, Customer Programs \& Services, Southern California Edison. May 2014. Accessed January 2015: http://www.etcc-ca.com/reports/et11sce2030-zne-new-home.

Steven Winter Associates (2011). Practical Residential Wall Systems: R-30 and Beyond. Prepared by Steven Winter Associates for the U.S. Department of Energy. Accessed January 2015: http://www.carb-swa.com/articles/homepage/R30_walls_final.pdf.

Straube, J. F.; Smegal, J. (2009). Building America Special Research Project: High-R Walls Case Study Analysis. Research Report - 0903. Somerville, MA: Building Science Corporation. 
Straube, J. (2011) Building America Special Research Project: High R-Value Enclosures for High Performance Residential Buildings in All Climate Zones. Building America Report - 1005 29 October 2010 (Rev. 1 February 2011). Building Science Corporation. Somerville, MA. 


\section{Appendix A: Builder Recruitment Process}

Site selection proceeded through various avenues including:

- DEG presented a webinar on July 15, 2013, in conjunction with Matt Christie (program manager for PG\&E's CAHP program) to introduce HERS raters and CAHP builders to the PG\&E Emerging Technology Program opportunity for high performance walls and ducts.

- DEG's ongoing work running Leadership in Energy \& Environmental Design for Homes in California and Building America research efforts puts us in front of many of the progressive builders in California, although many are small scale builders or semi-custom builders.

- Direct outreach to builders and contacts within the utility industry working on advanced residential building initiatives.

- Contact with Title 24 compliance companies and through the California Association of Building Energy Consultants.

- Attendance at PCBC in San Diego as well as several Building Industry Association events in the greater Sacramento area.

All of these options were explored to identify and communicate with potential builder candidates. In a few cases, builders were currently implementing the technology to the specifications identified for the project (or close to the project specifications), but generally, the recruitment process required talking through the advanced measures, providing information on the expected benefits of the technology, and working within their decision-making framework to determine if there was an opportunity to engage the builders in the project. The site selection process did not occur over a discrete time window, as we had originally anticipated when developing the project statement of work. All builders that we pursued proceeded on their own schedules as they worked through a range of issues that included:

- Gathering more information on the project opportunity

- Completing internal reviews within their organization to determine if the project opportunity was worth pursuing

- Having discussions with their subcontractors on their ability and desire to implement potential approaches and expected costs

- Focusing attention on ongoing construction activities as the market rebounded.

Builders who were identified and contacted and chose not to participate in the project are listed in Table 7. 
Table 7. Builders Contacted Who Chose Not To Participate

\begin{tabular}{|c|c|c|c|}
\hline Builder & Location(s) & Discussion of Measures & Reason for Not Participating \\
\hline $\begin{array}{l}\text { Taylor } \\
\text { Morrison }\end{array}$ & Rocklin & $\begin{array}{l}\text { Currently using } 2 \times 6 \text { wall } \\
\text { construction with } 1 \text {-in. R- } \\
4 \text { exterior in Rocklin } \\
\text { project }\end{array}$ & $\begin{array}{c}\text { Not interested in disruptions } \\
\text { associated with utility programs; too } \\
\text { busy }\end{array}$ \\
\hline $\begin{array}{l}\text { Cresleigh } \\
\text { Homes }\end{array}$ & Yuba City & $\begin{array}{l}\text { Have done some } 2 \times 6 \\
\text { walls in the past }\end{array}$ & $\begin{array}{c}\text { No projects with } 2 \times 6 \text { currently } \\
\text { planned }\end{array}$ \\
\hline Pulte Homes & $\begin{array}{l}\text { Lincoln, } \\
\text { East Bay, } \\
\text { San Jose }\end{array}$ & $\begin{array}{l}\text { Conditioned attics in some } \\
\text { areas where it builds }\end{array}$ & Too busy to focus on this effort \\
\hline Shea Homes & Rio Vista & $\begin{array}{l}\text { Prior limited experience } \\
\text { with conditioned attics }\end{array}$ & $\begin{array}{l}\text { Original contact we were pursuing } \\
\text { left the company; further follow-ups } \\
\text { were not responded to }\end{array}$ \\
\hline $\begin{array}{l}\text { Lennar } \\
\text { Homes }\end{array}$ & Fresno & $\begin{array}{l}\text { Building higher } \\
\text { performance homes in } \\
\text { area }\end{array}$ & Too busy to focus on this effort \\
\hline $\begin{array}{l}\text { Ellliott } \\
\text { Homes }\end{array}$ & Folsom & $\begin{array}{l}\text { Building high } \\
\text { performance homes with } 2 \\
\times 6 \text { walls and ducts in } \\
\text { conditioned space (but not } \\
\text { HVAC unit) }\end{array}$ & $\begin{array}{l}\text { Working under Sacramento } \\
\text { Municipal Utility District high } \\
\text { performance home program; } \\
\text { initiated a dialogue, but they } \\
\text { ultimately decided not to participate }\end{array}$ \\
\hline KB Homes & $\begin{array}{l}\text { Greater } \\
\text { Sacramento } \\
\text { area, } \\
\text { Fresno, } \\
\text { Stockton }\end{array}$ & $\begin{array}{c}\text { Has built advanced homes } \\
\text { with various measures, but } \\
\text { not apparently in northern } \\
\text { CA }\end{array}$ & $\begin{array}{l}\text { Initial lukewarm interest, but } \\
\text { decided not to participate. }\end{array}$ \\
\hline $\begin{array}{l}\text { Clarum } \\
\text { Homes }\end{array}$ & & Lighting, SIP walls & Only custom homes underway \\
\hline Landmark & & & $\begin{array}{l}\text { Initial interest at BIA event, but } \\
\text { follow-up was not successful }\end{array}$ \\
\hline $\begin{array}{l}\text { New Home } \\
\text { Company }\end{array}$ & $\begin{array}{l}\text { Will be } \\
\text { building } \\
\text { advanced } \\
\text { homes in } \\
2015\end{array}$ & & $\begin{array}{l}\text { Some interest, but not in the near } \\
\text { term; projects starting Q4 } 2014\end{array}$ \\
\hline $\begin{array}{c}\mathrm{K} \\
\text { Hovananian }\end{array}$ & & $\begin{array}{l}\text { Haven't implemented but } \\
\text { are interested in staying } \\
\text { informed }\end{array}$ & $\begin{array}{l}\text { No projects in the short term where } \\
\text { they are considering these measures }\end{array}$ \\
\hline JMC & & & $\begin{array}{l}\text { Limited interest, but haven’t } \\
\text { implemented previously }\end{array}$ \\
\hline Signature & & & $\begin{array}{l}\text { Building multifamily, but no projects } \\
\text { until the fall }\end{array}$ \\
\hline
\end{tabular}




\section{Appendix B: Honda House Double-Stud Wall}

The residential wall framing at the Honda Demonstration house (located at the Zero Net Energy West Village community at the University of California, Davis) utilizes a unique type of advanced, high R-value, wall framing design. This type of high performance framing consists of a double stud wall assembly (Figure 10) with an air gap between exterior and interior framed segments of the assembly. The cavity is blown with cellulose insulation (nominally R-33).

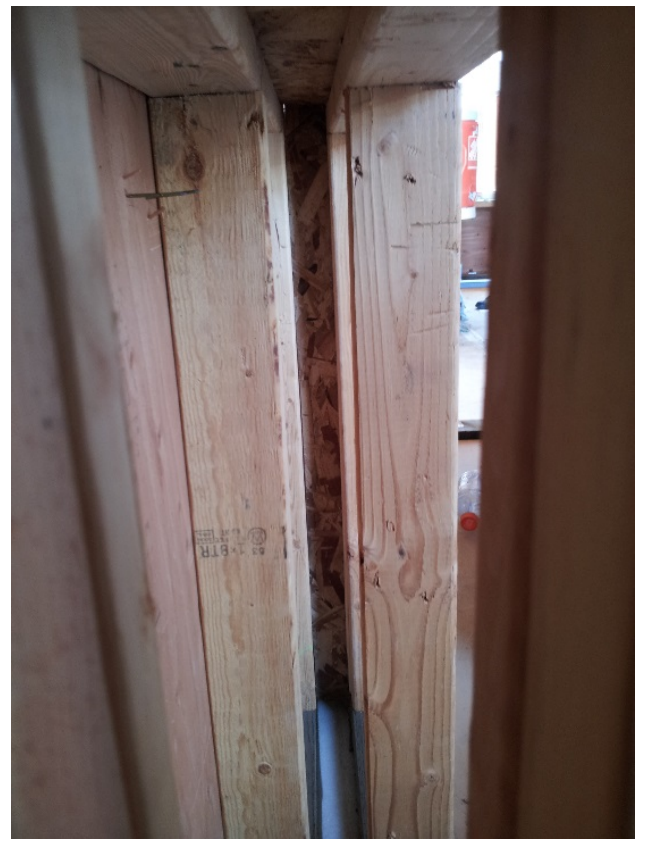

Figure 10. Lateral double-stud wall cavity view

In this implementation of double-stud wall framing, a 2-1/4-in. air gap was maintained throughout much of the wall assembly, allowing for the physical separation between exterior and interior $2 \times$ 4 framing members. The framing cavity is fully penetrated only through $3 / 4-i n$. OSB board at the perimeter of each window and door, at the top and bottom plates of the walls, and at floor framing between the first and second floors (see Figure 11 and Figure 12).

The one exception to the 2-1/4-in. gap between interior and exterior framing occurred at the great room wall. This particular wall (shown in Figure 13) resulted in a smaller $1 / 4$-in. air gap between interior and exterior studs by using $2 \times 6$ framing for the exterior wall and a standard $2 \times 4$ interior wall.

Detailed onsite wall takeoffs were completed by working sequentially around the house on each floor and identifying framing characteristics for "straight" wall sections. Measurements were taken to compute the type and lengths of all framing material present in both the exterior and interior wall assemblies, as well as for framing material that penetrated the full wall cavity. In each of these calculations, the framing factor for the wall segment utilized the corresponding wall segment area (wall segments identified from 1 to 22). Results of the wall takeoffs for the exterior, interior and total thermally bridged areas are presented in Figure 14. 


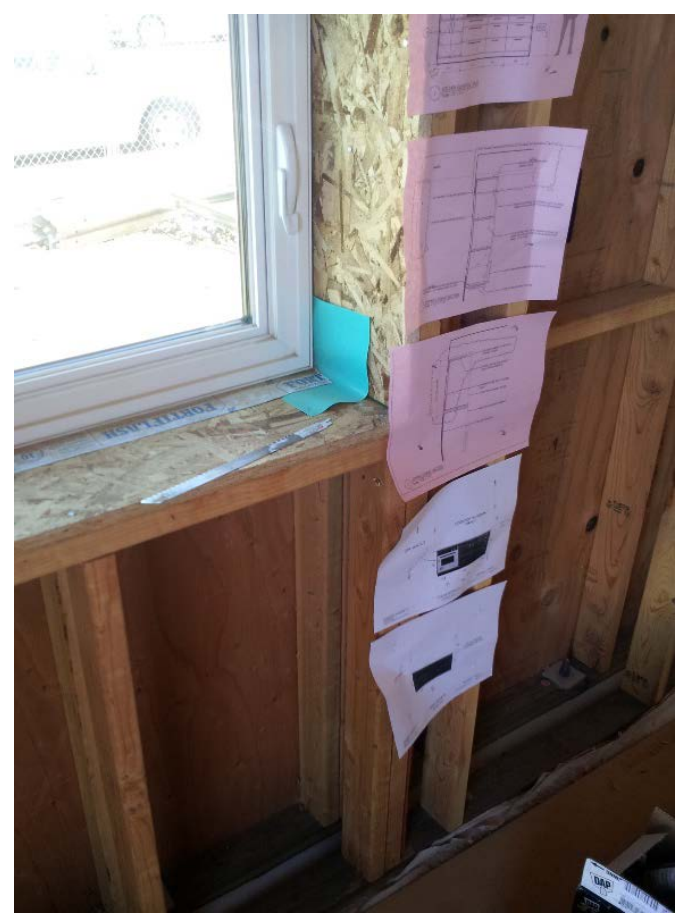

Figure 11. OSB framing detail at window

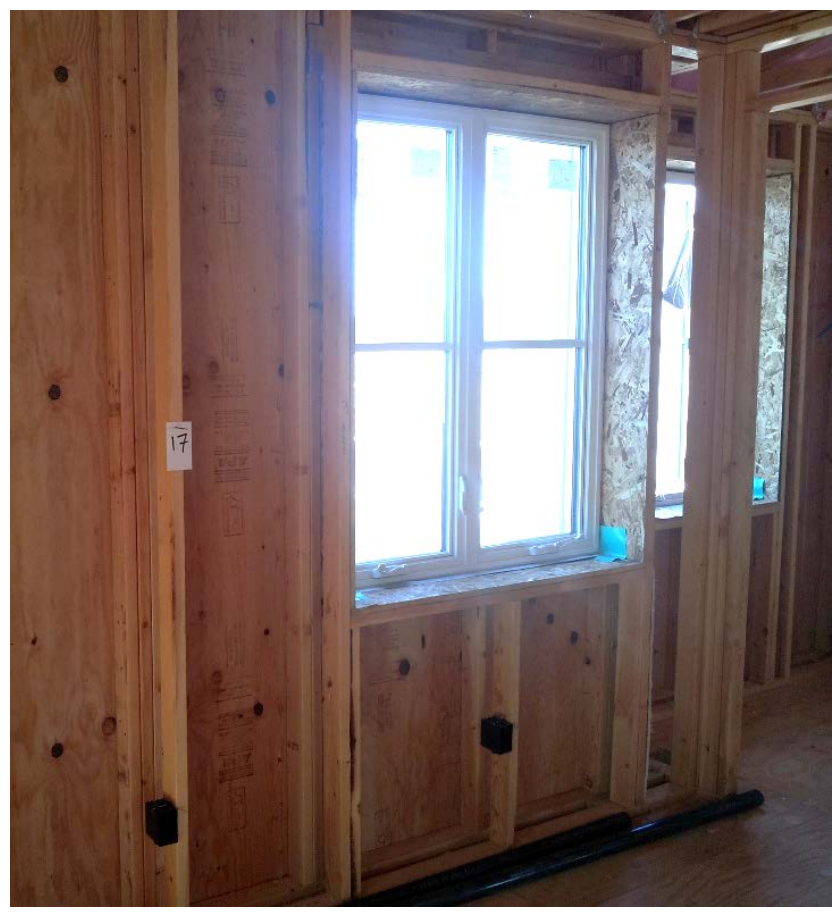

Figure 12. OSB board window perimeter connection 


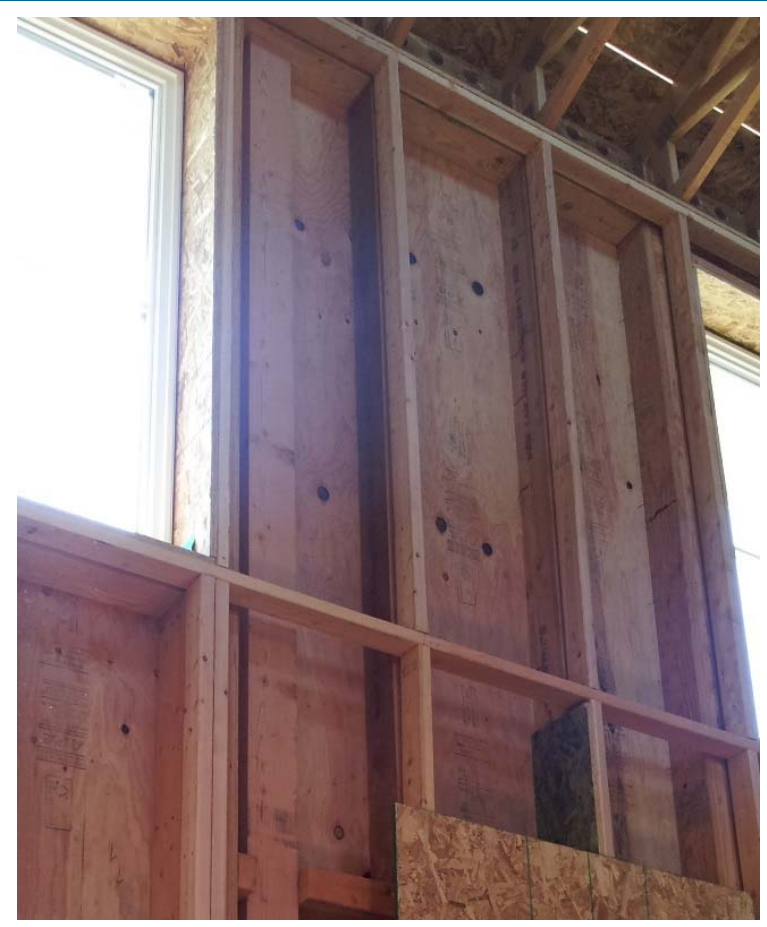

Figure 13. Great room double-stud wall with $1 / 4$-in. air gap between interior and exterior framing

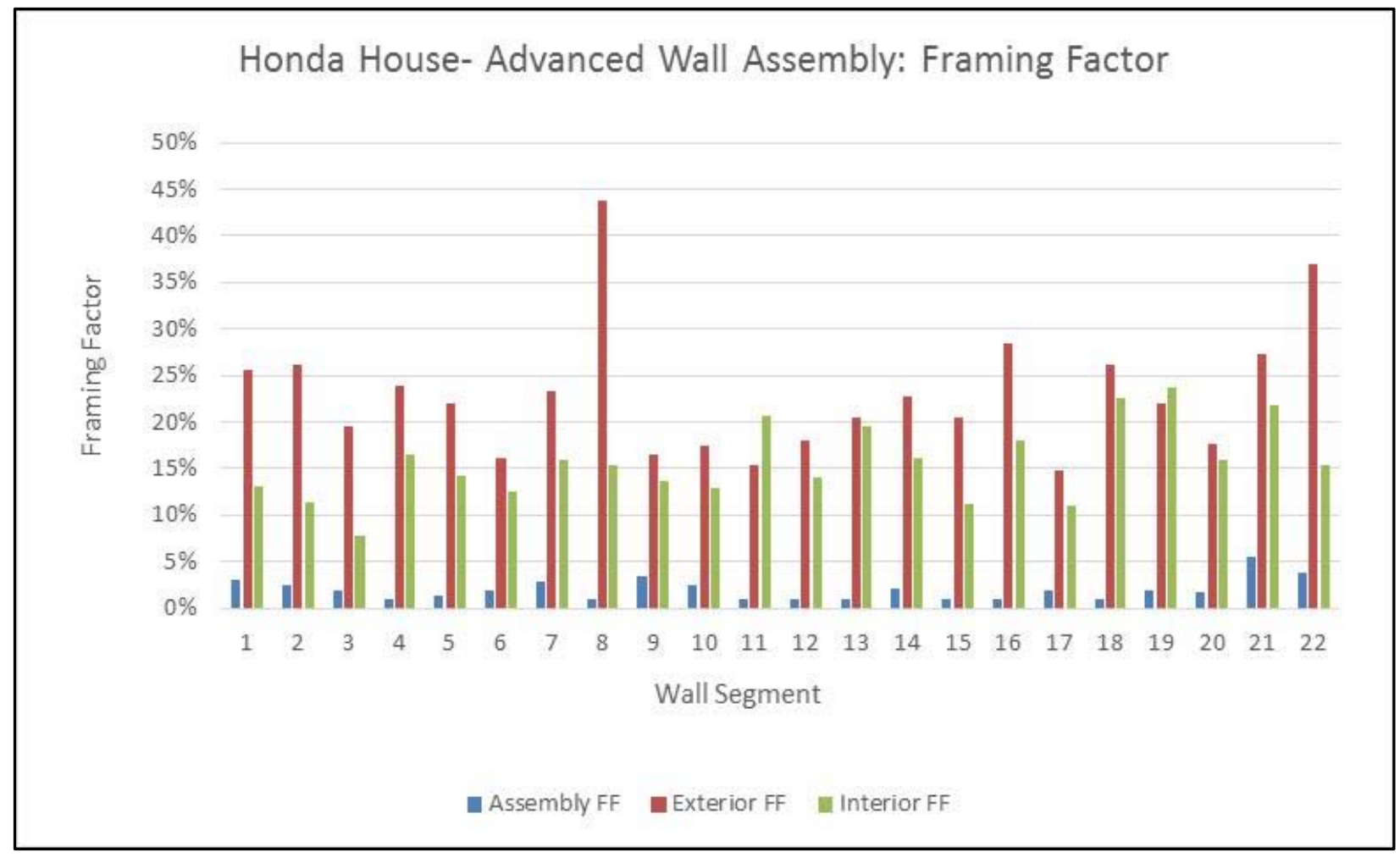

Figure 14. Wall section framing factors (full assembly, exterior, interior) 
Wall segments with high framing factors included locations where a large amount of studs were used for short wall sections (see segment 8) or where large amounts of windows necessitated additional framing (see segment 22). Aggregated over the entire house, the framing factors were $26 \%$ for the exterior wall, $17 \%$ for the interior wall, and $2.7 \%$ of framing penetrated the full depth of the wall assembly.

\section{THERM Evaluation}

Data from these detailed takeoffs were used as inputs for Lawrence Berkeley National Laboratory's Finite Element Simulator, THERM 7.2. The wall system geometry was broken down into six distinct wall cross-sections for the THERM evaluation. The six assembly configurations are characterized below and represented in Figure 15.

- Section A: $2 \times 4$ interior and exterior studs aligned with a 2-1/4-in. gap

- Section B: $2 \times 4$ interior and $2 \times 6$ exterior stud aligned with a $1 / 4$-in. gap

- Section C: Region with no studs and only drywall, insulation, and exterior sheathing

- Section D: $2 \times 4$ interior and exterior studs aligned with a 2-1/4-in. gap, at a height of 36 in.

- Section E: $2 \times 4$ exterior studs only

- $\quad$ Section F: Window frame sill area with $3 / 4$-in. OSB.

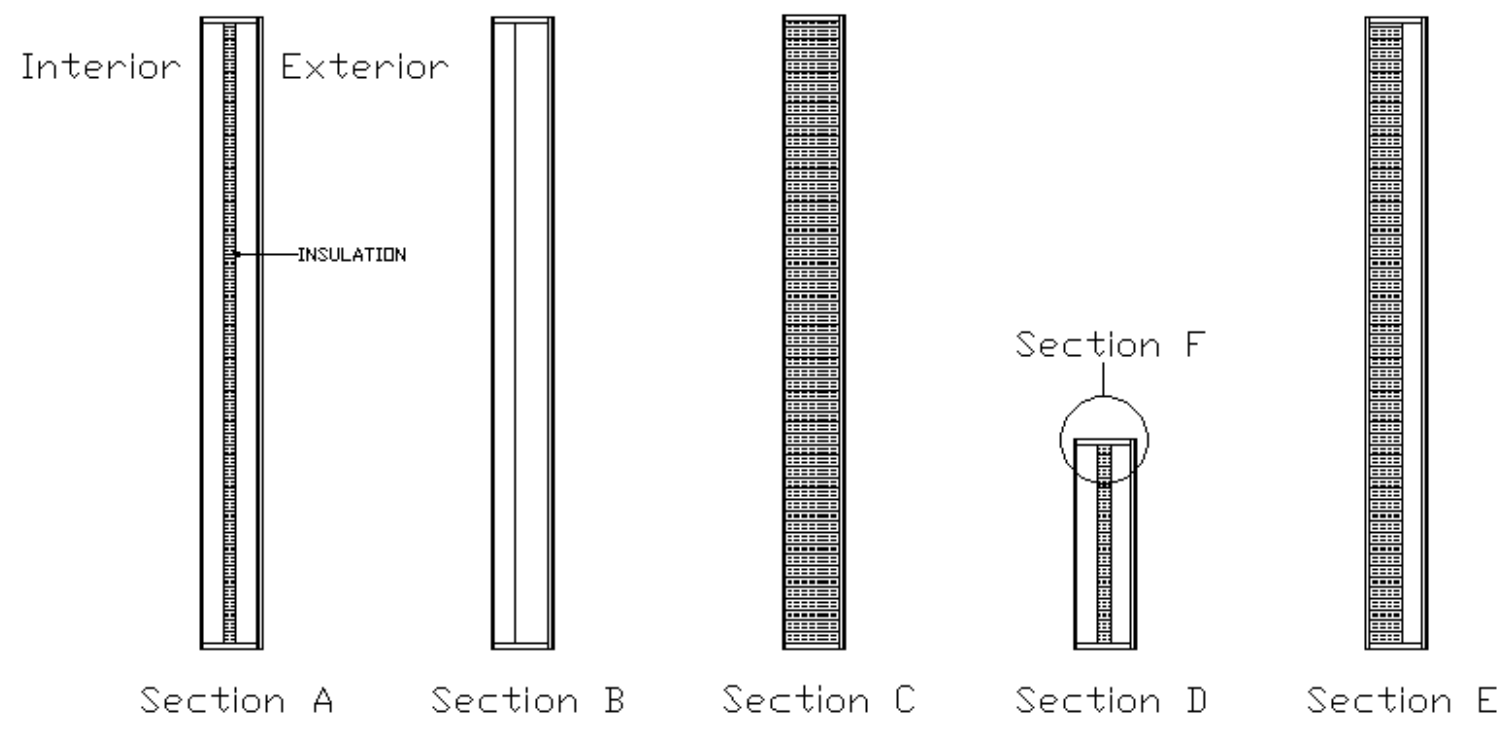

Figure 15. Representation of double-stud wall cross-sections

The THERM evaluation was completed for each element and a composite wall U-value was calculated by area weighting each element. Figure 16 presents the THERM results for each of the six assemblies with the area weighting percentage shown at the top of each bar. A wall 
composite R-value of 29.5 was determined, with a resultant U-value of $0.0339 \mathrm{Btu} / \mathrm{h}-\mathrm{ft}-{ }^{\circ} \mathrm{F}$. Note that this doesn't include the additional thermal bridging that the rim joist imposes in a multistory house.

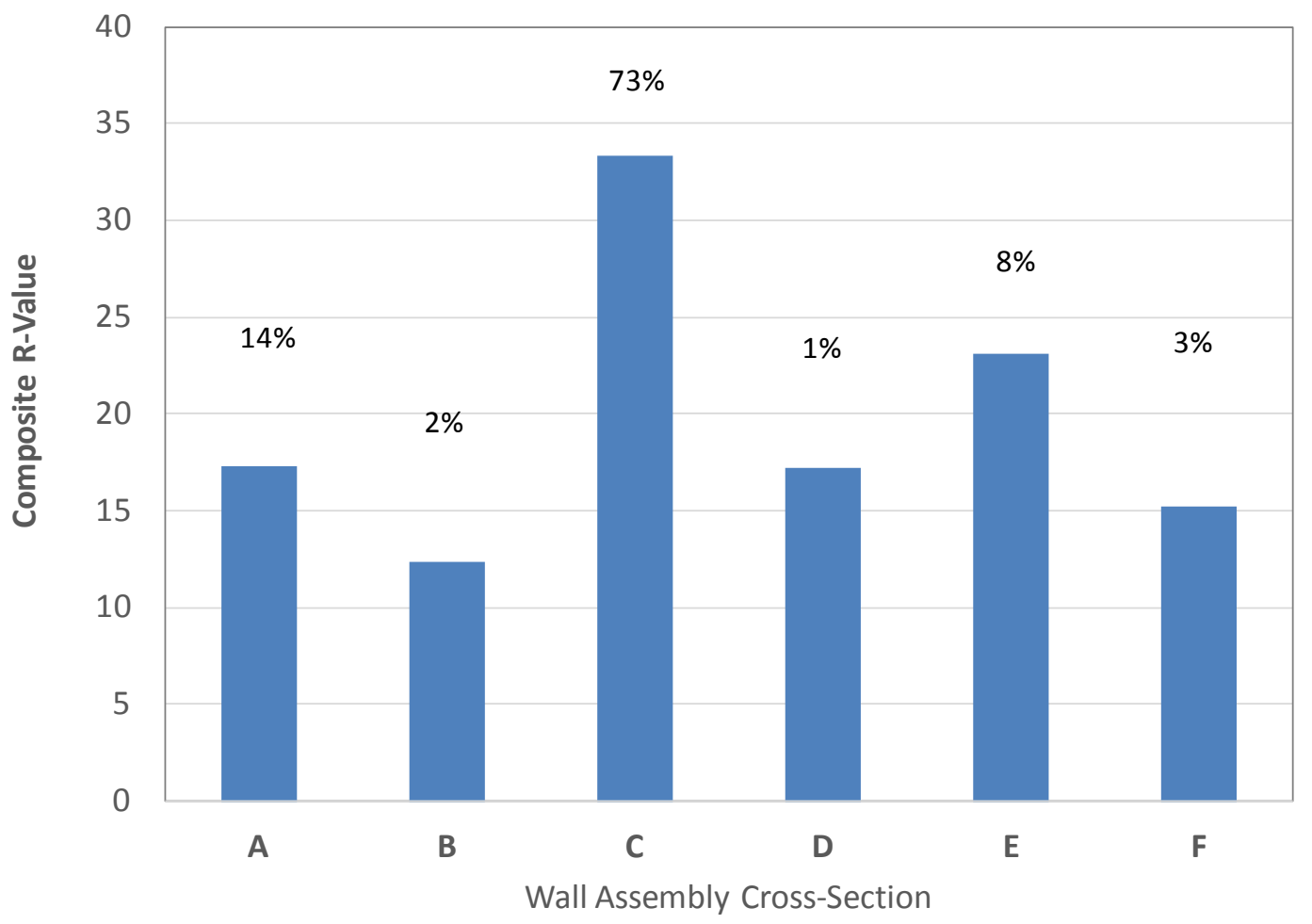

Figure 16. Assembly calculated R-values and area weighting 


\section{Appendix C: Cost Assumptions}

Incremental costs (material and labor) for exterior wall components and assemblies shown in Table 8 were developed from the following sources $(1-4)$ :

A. (1) = BEopt Cost Database

B. (2) = California Codes and Standards Enhancement work by TRC, funded by the California IOUs ${ }^{15}$

C. (3) = Builder and contractor supplied costs.

D. (4) = Materials pricing from suppliers and contractor outlets.

Table 8. Wall System Component Costs

\begin{tabular}{|c|c|c|}
\hline Component & $\begin{array}{c}\text { Unit Cost }\left(\$ / \mathbf{f t}^{2} \text { of }\right. \\
\text { Exterior Wall) }\end{array}$ & Source \\
\hline \multicolumn{3}{|c|}{ Cavity Insulation } \\
\hline R-13 Batt & $\$ 0.66$ & (1) \\
\hline R-19 Blown Cellulose & $\$ 0.87$ & (1) \\
\hline R-21 Batt & $\$ 0.94$ & Labor: (1), Material: (2) \\
\hline R-23 BIB & $\$ 1.22$ & Labor: (1), Material: (2)(3) \\
\hline R-33 Blown Cellulose & $\$ 1.92$ & (1) \\
\hline \multicolumn{3}{|c|}{ Wall Framing-Studs } \\
\hline $2 \times 4,16$ in. o.c. & $\$ 1.84$ & (1) \\
\hline $2 \times 6,16$ in. o.c. & $\$ 2.00$ & (1) \\
\hline $2 \times 6,24$ in. o.c. & $\$ 1.76(\$ 2.20)^{*}$ & (1) \\
\hline Double stud $2 \times 4,24$ in. o.c. & $\$ 3.20$ & (1) \\
\hline \multicolumn{3}{|c|}{ Wall Sheathing } \\
\hline OSB Sheathing & $\$ 0.44$ & $(3)$ \\
\hline 1 in. EPS, R-4 & $\$ 0.78$ & Labor: Average values from \\
\hline 1 in. XPS, R-5 & $\$ 1.10$ & $(1)(2)(3)$ \\
\hline 1 in. Polyiso, R-6 & $\$ 1.04$ & Material: Average values from \\
\hline 2 in. EPS, R-8 & $\$ 1.27$ & $(1)(2)(3)(4)$ \\
\hline \multicolumn{3}{|c|}{ Exterior Finish } \\
\hline \multirow{2}{*}{$\begin{array}{l}\text { Three-Coat Stucco Finish } \\
\text { One-Coat Stucco Finish } \\
\text { (minus foam sheathing) }\end{array}$} & $\$ 5.01$ & \multirow{2}{*}{$\$(1)$} \\
\hline & $\$ 3.98$ & \\
\hline
\end{tabular}

${ }^{15} \mathrm{http} / / /$ energy.ca.gov/title24/2016standards/prerulemaking/documents/2014-07-

21_workshop/case_reports/2016_Title_24_Draft_CASE_Report-High_Performance_Walls_and_QII.pdf 


\section{Appendix D: Framing Factor Summary}

Framing factors were calculated for eight houses with "base case" walls and four with high performance walls. Results are presented in Figure 17. "All wood" net framing factor includes all studs, headers, plates, blocking, and other associated framing while "full studs" framing factor represents only the full-length studs only.

\begin{tabular}{|c|c|c|c|c|c|c|c|c|}
\hline \multirow[b]{2}{*}{ Site } & \multirow[b]{2}{*}{ House Floor } & \multirow[b]{2}{*}{ \# of } & \multirow[b]{3}{*}{ Wall description } & \multirow[b]{2}{*}{ Gross Wall } & \multirow[b]{2}{*}{ Net Wall } & \multirow[b]{2}{*}{ Net Wall Area as } & \multicolumn{2}{|c|}{ Net Framing Factor } \\
\hline & & & & & & & & Full Height \\
\hline ID & Area, $\mathrm{ft} 2$ & stories & & Area, $\mathrm{ft} 2$ & Area, $\mathrm{ft2}$ & $\%$ of Floor Area & All Wood & Studs Only \\
\hline \multicolumn{9}{|c|}{ Builders with Walls Not Participating in Project } \\
\hline 1 & 3922 & 2 & $2 \times 4,16$ " oc (R-13.3 spray foam) + R-4 ext & 3871 & 3282 & $84 \%$ & $26.6 \%$ & $20.9 \%$ \\
\hline 2 & 1950 & 2 & $2 \times 4,16$ " oc, R-13+R-4 exterior & 2645 & 2314 & $119 \%$ & $26.5 \%$ & $20.6 \%$ \\
\hline 3 & 1777 & 1 & $2 \times 4,16$ " oc, R-13+R-4 exterior & 1996 & 1686 & $95 \%$ & $25.7 \%$ & $21.4 \%$ \\
\hline 4 & 1622 & 1 & $2 \times 4,16$ " oc, R-13+ R-4 exterior & 1964 & 1640 & $101 \%$ & $27.2 \%$ & $23.7 \%$ \\
\hline 5 & 2368 & 2 & 2x4, 16" oc, R-13 (no foam) & 2729 & 2338 & $99 \%$ & $33.3 \%$ & $20.4 \%$ \\
\hline 6 & 2605 & 2 & $2 \times 4,16$ " oc, R-13 (no foam) & 3023 & 2563 & $98 \%$ & $31.6 \%$ & $20.3 \%$ \\
\hline 7 & 3190 & 1 & $2 \times 6,16$ " oc (R-19+R-4 ext foam) & 2945 & 2403 & $75 \%$ & $31.2 \%$ & $18.1 \%$ \\
\hline 8 & 4197 & 2 & $2 \times 6,16$ " oc (R-19+R-4 ext foam) & 4693 & 3890 & $93 \%$ & $35.5 \%$ & $18.7 \%$ \\
\hline & & & & & & & & \\
\hline \multicolumn{9}{|c|}{ Advanced Wall Systems Participating in Project } \\
\hline 9 & 1870 & 1 & $2 \times 6,16$ " oc, $\mathrm{R}-23 \mathrm{BIB}+\mathrm{R}-4$ exterior & 1821 & 1437 & $77 \%$ & $25.7 \%$ & $22.4 \%$ \\
\hline 10 & 1698 & 1 & $2 \times 6,24$ " oc, R-19+ R-4 exterior & 1704 & 1483 & $87 \%$ & $21.3 \%$ & $15.0 \%$ \\
\hline 11 & 1816 & 1 & $2 \times 6,24$ " oc, R-19+R-4 exterior & 1713 & 1490 & $82 \%$ & $21.4 \%$ & $16.6 \%$ \\
\hline 12 & 2209 & 1 & $2 \times 6,16$ " oc, $\mathrm{R}-23 \mathrm{BIB}+\mathrm{R}-4$ exterior & 2342 & 1991 & $90 \%$ & $24.0 \%$ & $18.2 \%$ \\
\hline
\end{tabular}

Figure 17. Measured framing factor results 


\section{Appendix E: BEopt Modeling Results}

BEopt detailed simulation results for the $2,100-\mathrm{ft}^{2}$, one-story prototype.

\begin{tabular}{|c|c|c|c|c|c|c|c|c|c|c|c|}
\hline \multicolumn{12}{|c|}{ Sacramento 2,100 ft2 One-Story Prototype } \\
\hline & & \multirow[b]{2}{*}{ Benchmark } & \multicolumn{9}{|c|}{\begin{tabular}{|c|} 
Single Stud 16" OC \\
\end{tabular}} \\
\hline & & & $\begin{array}{c}\text { R-19+ } \\
\text { R-4 }\end{array}$ & $\begin{array}{c}\mathrm{R}-21+ \\
\mathrm{R}-4\end{array}$ & $\begin{array}{c}R-23+ \\
R-4\end{array}$ & \begin{tabular}{|c|} 
R-19+ \\
R-6 \\
\end{tabular} & \begin{tabular}{|c|}
$\mathrm{R}-21+$ \\
$\mathrm{R}-6$
\end{tabular} & \begin{tabular}{|c|}
$R-23+$ \\
R-6
\end{tabular} & $\begin{array}{c}\mathrm{R}-19+ \\
\mathrm{R}-8\end{array}$ & $\begin{array}{c}R-21+ \\
R-8\end{array}$ & $\begin{array}{c}R-23+ \\
R-8\end{array}$ \\
\hline Energy Related Costs, Annualized & {$[\$ / y r]$} & $\$ 1,759$ & $\$ 1,692$ & $\$ 1,691$ & $\$ 1,694$ & $\$ 1,686$ & $\$ 1,685$ & $\$ 1,689$ & $\$ 1,682$ & $\$ 1,682$ & $\$ 1,686$ \\
\hline Total Source Energy & {$[\mathrm{MMBtu} / \mathrm{yr}]$} & 149.44 & 142.72 & 142.46 & 142.24 & 142.12 & 141.9 & 141.71 & 141.64 & 141.45 & 141.28 \\
\hline Cooling Source Energy (electricity) & {$[\mathrm{MMBtu} / \mathrm{yr}]$} & 11.75 & 10.01 & 9.96 & 9.91 & 9.88 & 9.84 & 9.8 & 9.78 & 9.74 & 9.71 \\
\hline Heating Source Energy (gas) & {$[\mathrm{MMBtu} / \mathrm{yr}]$} & 31.63 & 27.44 & 27.26 & 27.11 & 27.03 & 26.88 & 26.75 & 26.71 & 26.58 & 26.46 \\
\hline HVAC Fan Source Energy (electricity) & {$[\mathrm{MMBtu} / \mathrm{yr}]$} & 5.63 & 4.83 & 4.8 & 4.78 & 4.77 & 4.74 & 4.72 & 4.71 & 4.69 & 4.67 \\
\hline Source Energy Savings & {$[\mathrm{MMBtu} / \mathrm{yr}]$} & 0 & 6.72 & 6.98 & 7.2 & 7.32 & 7.54 & 7.73 & 7.8 & 7.99 & 8.16 \\
\hline
\end{tabular}

\begin{tabular}{|c|c|c|c|c|c|c|c|c|c|c|c|}
\hline & & \multirow[b]{2}{*}{$\begin{array}{c}\text { Double } \\
\text { Stud }\end{array}$} & \multicolumn{9}{|c|}{ Single Stud 24" OC } \\
\hline & & & $\begin{array}{c}\mathrm{R}-19+ \\
\mathrm{R}-4\end{array}$ & $\begin{array}{c}\mathrm{R}-21+ \\
\mathrm{R}-4\end{array}$ & $\begin{array}{c}\mathrm{R}-23+ \\
\mathrm{R}-4\end{array}$ & $\begin{array}{c}\mathrm{R}-19+ \\
\mathrm{R}-6 \\
\end{array}$ & $\begin{array}{c}\mathrm{R}-21+ \\
\mathrm{R}-6 \\
\end{array}$ & $\begin{array}{c}\mathrm{R}-23+ \\
\mathrm{R}-6 \\
\end{array}$ & $\begin{array}{c}\mathrm{R}-19+ \\
\mathrm{R}-8\end{array}$ & $\begin{array}{c}\mathrm{R}-21+ \\
\mathrm{R}-8\end{array}$ & $\begin{array}{c}\mathrm{R}-23+ \\
\mathrm{R}-8\end{array}$ \\
\hline Energy Related Costs, Annualized & {$[\$ / y r]$} & $\$ 1,718$ & $\$ 1,690$ & $\$ 1,689$ & $\$ 1,693$ & $\$ 1,685$ & $\$ 1,684$ & $\$ 1,688$ & $\$ 1,682$ & $\$ 1,681$ & $\$ 1,686$ \\
\hline Total Source Energy & {$[\mathrm{MMBtu} / \mathrm{yr}]$} & 140.52 & 142.2 & 141.95 & 141.74 & 141.68 & 141.47 & 141.3 & 141.28 & 141.1 & 140.94 \\
\hline Cooling Source Energy (electricity) & {$[\mathrm{MMBtu} / \mathrm{yr}]$} & 9.53 & 9.88 & 9.83 & 9.79 & 9.77 & 9.73 & 9.7 & 9.69 & 9.66 & 9.63 \\
\hline Heating Source Energy (gas) & {$[\mathrm{MMBtu} / \mathrm{yr}]$} & 25.97 & 27.11 & 26.94 & 26.79 & 26.76 & 26.61 & 26.49 & 26.48 & 26.35 & 26.24 \\
\hline HVAC Fan Source Energy (electricity) & {$[\mathrm{MMBtu} / \mathrm{yr}]$} & 4.58 & 4.77 & 4.74 & 4.72 & 4.71 & 4.69 & 4.67 & 4.67 & 4.65 & 4.63 \\
\hline Source Energy Savings & {$[\mathrm{MMBtu} / \mathrm{yr}]$} & 8.91 & 7.24 & 7.49 & 7.7 & 7.76 & 7.97 & 8.14 & 8.16 & 8.34 & 8.5 \\
\hline
\end{tabular}

\begin{tabular}{|c|c|c|c|c|c|c|c|c|c|c|c|}
\hline \multicolumn{12}{|c|}{ Fresno $2,100 \mathrm{ft} 2$ One-Story Prototype } \\
\hline & & \multirow[b]{2}{*}{ Benchmark } & \multicolumn{9}{|c|}{\begin{tabular}{|c|} 
Single Stud 16" OC \\
\end{tabular}} \\
\hline & & & $\begin{array}{c}\text { R-19+ } \\
\text { R-4 }\end{array}$ & $\begin{array}{c}\text { R-21 + } \\
\text { R-4 }\end{array}$ & $\begin{array}{c}R-23+ \\
R-4\end{array}$ & \begin{tabular}{|c|} 
R-19 + \\
R-6
\end{tabular} & \begin{tabular}{|c|} 
R-21 + \\
R-6
\end{tabular} & $\begin{array}{c}\mathrm{R}-23+ \\
\mathrm{R}-6\end{array}$ & $\begin{array}{c}\text { R-19 + } \\
\text { R-8 }\end{array}$ & $\begin{array}{c}R-21+ \\
R-8\end{array}$ & $\begin{array}{c}\mathrm{R}-23+ \\
\mathrm{R}-8\end{array}$ \\
\hline Energy Related Costs, Annualized & {$[\$ / y r]$} & $\$ 1,846$ & $\$ 1,773$ & $\$ 1,771$ & $\$ 1,775$ & $\$ 1,766$ & $\$ 1,765$ & $\$ 1,769$ & $\$ 1,762$ & $\$ 1,761$ & $\$ 1,765$ \\
\hline Total Source Energy & {$[\mathrm{MMBtu} / \mathrm{yr}]$} & 155.89 & 148.75 & 148.46 & 148.22 & 148.1 & 147.86 & 147.65 & 147.58 & 147.36 & 147.19 \\
\hline Cooling Source Energy (electricity) & [MMBtu/yr] & 23.07 & 20.46 & 20.36 & 20.28 & 20.24 & 20.16 & 20.09 & 20.06 & 19.99 & 19.94 \\
\hline Heating Source Energy (gas) & {$[\mathrm{MMBtu} / \mathrm{yr}]$} & 25.64 & 22.06 & 21.91 & 21.78 & 21.72 & 21.59 & 21.47 & 21.44 & 21.32 & 21.22 \\
\hline HVAC Fan Source Energy (electricity) & {$[\mathrm{MMBtu} / \mathrm{yr}]$} & 8.16 & 7.21 & 7.17 & 7.14 & 7.12 & 7.09 & 7.07 & 7.06 & 7.03 & 7.01 \\
\hline Source Energy Savings & {$[\mathrm{MMBtu} / \mathrm{yr}]$} & 0 & 7.14 & 7.43 & 7.67 & 7.79 & 8.03 & 8.24 & 8.31 & 8.53 & 8.7 \\
\hline
\end{tabular}

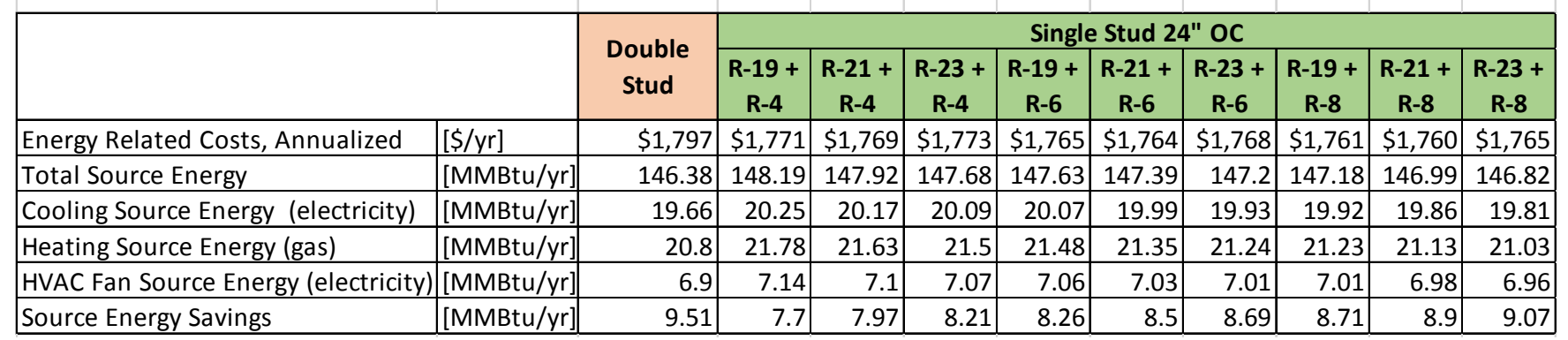




\begin{tabular}{|c|c|c|c|c|c|c|c|c|c|c|c|}
\hline \multicolumn{12}{|c|}{ Albuquerque 2,100 ft2 One-Story Prototype } \\
\hline & & \multirow[b]{2}{*}{ Benchmark } & \multicolumn{9}{|c|}{\begin{tabular}{|c|} 
Single Stud 16" OC \\
\end{tabular}} \\
\hline & & & $\begin{array}{c}\text { R-19 + } \\
\text { R-4 } \\
\end{array}$ & \begin{tabular}{|c|}
$R-21+$ \\
$R-4$ \\
\end{tabular} & \begin{tabular}{|c|}
$R-23+$ \\
$R-4$
\end{tabular} & \begin{tabular}{|c|} 
R-19 + \\
R-6 \\
\end{tabular} & \begin{tabular}{|c|} 
R-21 + \\
R-6 \\
\end{tabular} & \begin{tabular}{|c|}
$R-23+$ \\
$R-6$ \\
\end{tabular} & \begin{tabular}{|c|}
$R-19+$ \\
$R-8$ \\
\end{tabular} & $\begin{array}{c}\mathrm{R}-21+ \\
\mathrm{R}-8\end{array}$ & $\begin{array}{c}\text { R-23 + } \\
\text { R-8 } \\
\end{array}$ \\
\hline Energy Related Costs, Annualized & {$[\$ / \mathrm{yr}]$} & $\$ 1,962$ & $\$ 1,883$ & $\$ 1,881$ & $\$ 1,884$ & $\$ 1,876$ & $\$ 1,874$ & $\$ 1,878$ & $\$ 1,870$ & $\$ 1,869$ & $\$ 1,873$ \\
\hline Total Source Energy & {$[\mathrm{MMBtu} / \mathrm{yr}]$} & 171.35 & 163.36 & 163.02 & 162.72 & 162.58 & 162.29 & 162.05 & 161.96 & 161.71 & 161.5 \\
\hline Cooling Source Energy (electricity) & {$[\mathrm{MMBtu} / \mathrm{yr}]$} & 10.3 & 8.87 & 8.82 & 8.78 & 8.75 & 8.71 & 8.68 & 8.66 & 8.63 & 8.6 \\
\hline Heating Source Energy (gas) & {$[\mathrm{MMBtu} / \mathrm{yr}]$} & 51.29 & 45.66 & 45.41 & 45.19 & 45.09 & 44.87 & 44.69 & 44.63 & 44.44 & 44.28 \\
\hline HVAC Fan Source Energy (electricity) & {$[\mathrm{MMBtu} / \mathrm{yr}]$} & 7.83 & 6.89 & 6.85 & 6.81 & 6.8 & 6.77 & 6.74 & 6.73 & 6.7 & 6.68 \\
\hline Source Energy Savings & {$[\mathrm{MMBtu} / \mathrm{yr}]$} & 0 & 7.99 & 8.33 & 8.63 & 8.77 & 9.06 & 9.3 & 9.39 & 9.64 & 9.85 \\
\hline
\end{tabular}

\begin{tabular}{|c|c|c|c|c|c|c|c|c|c|c|c|}
\hline & & \multirow[b]{2}{*}{$\begin{array}{c}\text { Double } \\
\text { Stud }\end{array}$} & \multicolumn{9}{|c|}{ Single Stud 24" OC } \\
\hline & & & $\begin{array}{c}\text { R-19 + } \\
\text { R-4 }\end{array}$ & $\begin{array}{c}\mathrm{R}-21+ \\
\mathrm{R}-4\end{array}$ & $\begin{array}{c}R-23+ \\
R-4\end{array}$ & $\begin{array}{c}\mathrm{R}-19+ \\
\mathrm{R}-6\end{array}$ & $\begin{array}{c}\mathrm{R}-21+ \\
\mathrm{R}-6\end{array}$ & \begin{tabular}{|c|}
$\mathrm{R}-23+$ \\
$\mathrm{R}-6$
\end{tabular} & $\begin{array}{c}R-19+ \\
R-8\end{array}$ & $\begin{array}{c}\text { R-21 + } \\
\text { R-8 }\end{array}$ & $\begin{array}{c}R-23+ \\
R-8\end{array}$ \\
\hline Energy Related Costs, Annualized & {$[\$ / y r]$} & $\$ 1,904$ & $\$ 1,880$ & $\$ 1,879$ & $\$ 1,882$ & $\$ 1,874$ & $\$ 1,872$ & $\$ 1,876$ & $\$ 1,869$ & $\$ 1,868$ & $\$ 1,872$ \\
\hline Total Source Energy & {$[\mathrm{MMBtu} / \mathrm{yr}]$} & 160.59 & 162.72 & 162.41 & 162.12 & 162.06 & 161.78 & 161.54 & 161.52 & 161.28 & 161.08 \\
\hline Cooling Source Energy (electricity) & {$[\mathrm{MMBtu} / \mathrm{yr}]$} & 8.45 & 8.75 & 8.71 & 8.67 & 8.66 & 8.62 & 8.59 & 8.58 & 8.55 & 8.53 \\
\hline Heating Source Energy (gas) & {$[\mathrm{MMBtu} / \mathrm{yr}]$} & 43.63 & 45.22 & 44.98 & 44.77 & 44.72 & 44.51 & 44.33 & 44.32 & 44.14 & 43.98 \\
\hline HVAC Fan Source Energy (electricity) & [MMBtu/yr] & 6.57 & 6.81 & 6.78 & 6.74 & 6.74 & 6.71 & 6.68 & 6.68 & 6.65 & 6.63 \\
\hline Source Energy Savings & {$[\mathrm{MMBtu} / \mathrm{yr}]$} & 10.76 & 8.63 & 8.94 & 9.23 & 9.29 & 9.57 & 9.81 & 9.83 & 10.07 & 10.27 \\
\hline
\end{tabular}

Phoenix 2,100 ft2 One-Story Prototype

\begin{tabular}{|c|c|c|c|c|c|c|c|c|c|c|c|}
\hline & & \multirow[b]{2}{*}{ Benchmark } & \multicolumn{9}{|c|}{ Single Stud 16" OC } \\
\hline & & & $\begin{array}{c}\text { R-19 + } \\
\text { R-4 }\end{array}$ & $\begin{array}{c}\mathrm{R}-21+ \\
\mathrm{R}-4\end{array}$ & $\begin{array}{c}R-23+ \\
R-4\end{array}$ & \begin{tabular}{|c|} 
R-19 + \\
R-6
\end{tabular} & \begin{tabular}{|c|} 
R-21 + \\
R-6
\end{tabular} & \begin{tabular}{|c|} 
R-23 + \\
R-6
\end{tabular} & $\begin{array}{c}R-19+ \\
R-8\end{array}$ & $\begin{array}{c}\mathrm{R}-21+ \\
\mathrm{R}-8\end{array}$ & $\begin{array}{c}R-23+ \\
R-8\end{array}$ \\
\hline Energy Related Costs, Annualized & {$[\$ / y r]$} & $\$ 2,104$ & $\$ 2,020$ & $\$ 2,018$ & $\$ 2,020$ & $\$ 2,012$ & $\$ 2,010$ & $\$ 2,013$ & $\$ 2,006$ & $\$ 2,005$ & $\$ 2,009$ \\
\hline Total Source Energy & {$[\mathrm{MMBtu} / \mathrm{yr}]$} & 174.56 & \begin{tabular}{|l|}
166.71 \\
\end{tabular} & 166.4 & 166.13 & 165.98 & 165.73 & \begin{tabular}{|l|}
165.49 \\
\end{tabular} & 165.4 & 165.17 & 164.97 \\
\hline Cooling Source Energy (electricity) & {$[\mathrm{MMBtu} / \mathrm{yr}]$} & 59.88 & \begin{tabular}{|l|}
54.76 \\
\end{tabular} & 54.55 & 54.37 & \begin{tabular}{|l|}
54.27 \\
\end{tabular} & \begin{tabular}{|r|}
54.1 \\
\end{tabular} & 53.94 & 53.89 & 53.73 & 53.59 \\
\hline Heating Source Energy (gas) & {$[\mathrm{MMBtu} / \mathrm{yr}]$} & 4.67 & 3.28 & 3.23 & 3.19 & 3.17 & 3.13 & 3.09 & 3.07 & 3.04 & 3.01 \\
\hline HVAC Fan Source Energy (electricity) & {$[\mathrm{MMBtu} / \mathrm{yr}]$} & 15.09 & 13.76 & 13.71 & 13.66 & 13.63 & 13.59 & 13.55 & 13.53 & 13.49 & 13.46 \\
\hline Source Energy Savings & {$[\mathrm{MMBtu} / \mathrm{yr}]$} & 0 & 7.85 & 8.16 & 8.43 & 8.58 & 8.83 & 9.07 & 9.16 & 9.39 & 9.59 \\
\hline
\end{tabular}

\begin{tabular}{|c|c|c|c|c|c|c|c|c|c|c|c|}
\hline & \multirow{2}{*}{$\begin{array}{c}\text { Double } \\
\text { Stud }\end{array}$} & \multicolumn{9}{|c|}{ Single Stud 24" OC } \\
\hline & & & $\begin{array}{c}\text { R-19 + } \\
\text { R-4 }\end{array}$ & $\begin{array}{c}\text { R-21 + } \\
\text { R-4 }\end{array}$ & $\begin{array}{c}\mathrm{R}-23+ \\
\mathrm{R}-4\end{array}$ & $\begin{array}{c}\text { R-19 + } \\
\text { R-6 }\end{array}$ & $\begin{array}{c}\text { R-21 + } \\
\text { R-6 }\end{array}$ & $\begin{array}{c}\text { R-23 + } \\
\text { R-6 }\end{array}$ & $\begin{array}{c}\text { R-19 + } \\
\text { R-8 }\end{array}$ & $\begin{array}{c}\text { R-21 + } \\
\text { R-8 }\end{array}$ & $\begin{array}{c}\text { R-23 + } \\
\text { R-8 }\end{array}$ \\
\hline Energy Related Costs, Annualized & {$[\$ / y r]$} & $\$ 2,039$ & $\$ 2,017$ & $\$ 2,015$ & $\$ 2,018$ & $\$ 2,010$ & $\$ 2,008$ & $\$ 2,012$ & $\$ 2,005$ & $\$ 2,004$ & $\$ 2,008$ \\
\hline Total Source Energy & {$[\mathrm{MMBtu} / \mathrm{yr}]$} & 164.12 & 166.12 & 165.81 & 165.55 & 165.47 & 165.22 & 165 & 164.97 & 164.75 & 164.56 \\
\hline Cooling Source Energy (electricity) & {$[\mathrm{MMBtu} / \mathrm{yr}]$} & 53.07 & 54.38 & 54.17 & 54 & 53.95 & 53.78 & 53.63 & 53.62 & 53.47 & 53.34 \\
\hline Heating Source Energy (gas) & {$[\mathrm{MMBtu} / \mathrm{yr}]$} & 2.83 & 3.17 & 3.12 & 3.09 & 3.07 & 3.03 & 3 & 2.99 & 2.96 & 2.93 \\
\hline HVAC Fan Source Energy (electricity) & {$[\mathrm{MMBtu} / \mathrm{yr}]$} & 13.32 & 13.66 & 13.61 & 13.56 & 13.55 & 13.51 & 13.47 & 13.46 & 13.42 & 13.39 \\
\hline Source Energy Savings & {$[\mathrm{MMBtu} / \mathrm{yr}]$} & 10.44 & 8.44 & 8.75 & 9.01 & 9.09 & 9.34 & 9.56 & 9.59 & 9.81 & 10 \\
\hline
\end{tabular}


BEopt detailed simulation results for the $2,700-\mathrm{ft}^{2}$, two-story prototype.

\begin{tabular}{|c|c|c|c|c|c|c|c|c|c|c|c|}
\hline \multicolumn{12}{|c|}{ Sacramento $2,700 \mathrm{ft}^{2}$ 2-Story Prototype } \\
\hline & & \multirow[b]{2}{*}{ Benchmark } & \multicolumn{9}{|c|}{\begin{tabular}{|c|} 
Single Stud 16" OC \\
\end{tabular}} \\
\hline & & & \begin{tabular}{|c|}
$R-21+$ \\
$R-4$ \\
\end{tabular} & \begin{tabular}{|c|}
$R-19+$ \\
$R-4$ \\
\end{tabular} & \begin{tabular}{|c|}
$R-23+$ \\
$R-4$
\end{tabular} & $\begin{array}{c}\mathrm{R}-21+ \\
\mathrm{R}-6\end{array}$ & $\begin{array}{c}\mathrm{R}-19+ \\
\mathrm{R}-6 \\
\end{array}$ & $\begin{array}{c}\mathrm{R}-23+ \\
\mathrm{R}-6 \\
\end{array}$ & \begin{tabular}{|c|} 
R-21 + \\
R-8 \\
\end{tabular} & \begin{tabular}{|c|}
$R-19+$ \\
$R-8$
\end{tabular} & $\begin{array}{c}\mathrm{R}-23+ \\
\mathrm{R}-8 \\
\end{array}$ \\
\hline Energy Related Costs, Annualized & {$[\$ / y r]$} & $\$ 2,012$ & $\$ 1,914$ & $\$ 1,915$ & $\$ 1,920$ & $\$ 1,906$ & $\$ 1,907$ & $\$ 1,913$ & $\$ 1,900$ & $\$ 1,900$ & $\$ 1,907$ \\
\hline Total Source Energy & {$[\mathrm{MMBtu} / \mathrm{yr}]$} & 173.97 & 163.71 & 164.11 & 163.37 & 162.88 & 163.21 & 162.58 & 162.2 & 162.49 & 161.95 \\
\hline Cooling Source Energy (electricity) & {$[\mathrm{MMBtu} / \mathrm{yr}]$} & 16.91 & 14.66 & 14.73 & 14.61 & 14.53 & 14.58 & 14.48 & 14.42 & 14.46 & 14.38 \\
\hline Heating Source Energy (gas) & [MMBtu/yr] & 41.73 & 34.83 & 35.13 & 34.58 & 34.22 & 34.47 & 34 & 33.72 & 33.94 & 33.53 \\
\hline HVAC Fan Source Energy (electricity) & {$[\mathrm{MMBtu} / \mathrm{yr}]$} & 7.86 & 6.75 & 6.78 & 6.71 & 6.66 & 6.69 & 6.63 & 6.59 & 6.62 & 6.57 \\
\hline \begin{tabular}{|l|} 
Source Energy Savings \\
\end{tabular} & {$[\mathrm{MMBtu} / \mathrm{yr}]$} & 0 & 10.26 & 9.86 & 10.6 & 11.09 & 10.76 & 11.39 & 11.77 & 11.48 & 12.02 \\
\hline
\end{tabular}

\begin{tabular}{|c|c|c|c|c|c|c|c|c|c|c|c|}
\hline & & \multirow[b]{2}{*}{$\begin{array}{c}\text { Double } \\
\text { Stud }\end{array}$} & \multicolumn{9}{|c|}{ Single Stud 24" OC } \\
\hline & & & $\begin{array}{c}\mathrm{R}-21+ \\
\mathrm{R}-6\end{array}$ & $\begin{array}{c}\text { R-19 + } \\
\text { R-6 }\end{array}$ & $\begin{array}{c}\mathrm{R}-23+ \\
\mathrm{R}-6\end{array}$ & \begin{tabular}{|c|} 
R-21 + \\
R-4
\end{tabular} & \begin{tabular}{|c|} 
R-19 + \\
R-4
\end{tabular} & $\begin{array}{c}\mathrm{R}-23+ \\
\mathrm{R}-4\end{array}$ & $\begin{array}{c}R-21+ \\
R-8\end{array}$ & $\begin{array}{c}\mathrm{R}-19+ \\
\mathrm{R}-8\end{array}$ & $\begin{array}{c}\text { R-23 + } \\
\text { R-8 }\end{array}$ \\
\hline Energy Related Costs, Annualized & {$[\$ / y r]$} & $\$ 1,978$ & $\$ 1,906$ & $\$ 1,907$ & $\$ 1,913$ & $\$ 1,913$ & $\$ 1,914$ & $\$ 1,919$ & $\$ 1,901$ & $\$ 1,901$ & $\$ 1,909$ \\
\hline Total Source Energy & {$[\mathrm{MMBtu} / \mathrm{yr}]$} & 160.92 & 162.29 & 162.6 & \begin{tabular}{|l|}
162.01 \\
\end{tabular} & 162.99 & 163.36 & 162.67 & 161.72 & \begin{tabular}{|r|}
162 \\
\end{tabular} & 161.5 \\
\hline Cooling Source Energy (electricity) & {$[\mathrm{MMBtu} / \mathrm{yr}]$} & 14.19 & 14.4 & 14.44 & 14.36 & 14.5 & 14.56 & 14.46 & 14.32 & 14.36 & 14.3 \\
\hline Heating Source Energy (gas) & {$[\mathrm{MMBtu} / \mathrm{yr}]$} & 32.8 & 33.82 & 34.06 & 33.61 & 34.35 & 34.63 & 34.1 & 33.39 & 33.6 & 33.21 \\
\hline HVAC Fan Source Energy (electricity) & {$[\mathrm{MMBtu} / \mathrm{yr}]$} & 6.46 & 6.6 & 6.63 & 6.57 & 6.67 & 6.7 & 6.64 & 6.54 & 6.57 & 6.52 \\
\hline Source Energy Savings & {$[\mathrm{MMBtu} / \mathrm{yr}]$} & 13.04 & 11.68 & 11.37 & 11.96 & 10.98 & 10.61 & 11.3 & 12.25 & 11.97 & 12.47 \\
\hline
\end{tabular}

\begin{tabular}{|c|c|c|c|c|c|c|c|c|c|c|c|}
\hline \multicolumn{12}{|c|}{ Fresno 2,700 $\mathrm{ft}^{2}$ 2-Story Prototype } \\
\hline & & \multirow[b]{2}{*}{ Benchmark } & \multicolumn{9}{|c|}{ Single Stud 16" OC } \\
\hline & & & \begin{tabular}{|c|}
$R-21+$ \\
$R-4$
\end{tabular} & $\begin{array}{c}\text { R-19 + } \\
\text { R-4 }\end{array}$ & $\begin{array}{c}\text { R-23 + } \\
\text { R-4 }\end{array}$ & $\begin{array}{c}\text { R-21 + } \\
\text { R-6 }\end{array}$ & $\begin{array}{c}\text { R-19 + } \\
\text { R-6 }\end{array}$ & \begin{tabular}{|c|} 
R-23 + \\
R-6
\end{tabular} & $\begin{array}{c}\text { R-21 + } \\
\text { R-8 }\end{array}$ & $\begin{array}{c}\text { R-19 + } \\
\text { R-8 }\end{array}$ & $\begin{array}{c}\text { R-23 + } \\
\text { R-8 }\end{array}$ \\
\hline Energy Related Costs, Annualized & {$[\$ / y r]$} & $\$ 2,122$ & $\$ 1,857$ & $\$ 1,859$ & $\$ 1,863$ & $\$ 1,848$ & $\$ 1,850$ & $\$ 1,855$ & $\$ 1,841$ & $\$ 1,842$ & $\$ 1,849$ \\
\hline Total Source Energy & {$[\mathrm{MMBtu} / \mathrm{yr}]$} & 182.23 & \begin{tabular}{|l|}
171.2 \\
\end{tabular} & 171.65 & 170.83 & 170.28 & 170.66 & 169.95 & 169.53 & 169.86 & 169.25 \\
\hline Cooling Source Energy (electricity) & {$[\mathrm{MMBtu} / \mathrm{yr}]$} & 30.79 & 27.09 & 27.23 & 26.98 & 26.81 & 26.92 & 26.71 & 26.58 & 26.68 & 26.5 \\
\hline Heating Source Energy (gas) & [MMBtu/yr] & 34.4 & 28.47 & 28.72 & 28.25 & 27.94 & 28.16 & 27.75 & 27.51 & 27.7 & 27.35 \\
\hline HVAC Fan Source Energy (electricity & {$[\mathrm{MMBtu} / \mathrm{yr}]$} & 10.96 & 9.56 & 9.62 & 9.52 & 9.45 & 9.5 & 9.41 & 9.36 & 9.4 & 9.32 \\
\hline Source Energy Savings & [MMBtu/yr] & 0 & 11.03 & 10.58 & 11.4 & 11.95 & 11.57 & 12.28 & 12.7 & 12.37 & 12.98 \\
\hline
\end{tabular}

\begin{tabular}{|c|c|c|c|c|c|c|c|c|c|c|c|}
\hline & \multirow[b]{2}{*}{$\begin{array}{c}\text { Double } \\
\text { Stud }\end{array}$} & \multicolumn{9}{|c|}{ Single Stud 24" OC } \\
\hline & & & $\begin{array}{c}\text { R-21 + } \\
\text { R-6 } \\
\end{array}$ & $\begin{array}{c}\text { R-19 + } \\
\text { R-6 } \\
\end{array}$ & $\begin{array}{c}\mathrm{R}-23+ \\
\mathrm{R}-6 \\
\end{array}$ & \begin{tabular}{|c}
$R-21+$ \\
R-4 \\
\end{tabular} & \begin{tabular}{|c|} 
R-19 + \\
R-4 \\
\end{tabular} & $\begin{array}{c}\text { R-23 + } \\
\text { R-4 } \\
\end{array}$ & $\begin{array}{c}R-21+ \\
R-8 \\
\end{array}$ & $\begin{array}{c}\text { R-19 + } \\
\text { R-8 } \\
\end{array}$ & $\begin{array}{c}\text { R-23 + } \\
\text { R-8 } \\
\end{array}$ \\
\hline Energy Related Costs, Annualized & {$[\$ / \mathrm{yr}]$} & $\$ 1,918$ & $\$ 1,848$ & $\$ 1,849$ & $\$ 1,855$ & $\$ 1,855$ & $\$ 1,857$ & $\$ 1,861$ & $\$ 1,842$ & $\$ 1,843$ & $\$ 1,850$ \\
\hline Total Source Energy & {$[\mathrm{MMBtu} / \mathrm{yr}]$} & 168.11 & 169.63 & 169.97 & 169.32 & 170.41 & 170.82 & 170.05 & 169 & 169.3 & 168.74 \\
\hline Cooling Source Energy (electricity) & {$[\mathrm{MMBtu} / \mathrm{yr}]$} & 26.14 & 26.59 & 26.69 & 26.5 & 26.82 & 26.94 & 26.72 & 26.41 & 26.49 & 26.34 \\
\hline Heating Source Energy (gas) & {$[\mathrm{MMBtu} / \mathrm{yr}]$} & 26.71 & 27.59 & 27.79 & 27.41 & 28.04 & 28.28 & 27.83 & 27.22 & 27.4 & 27.06 \\
\hline HVAC Fan Source Energy (electricity & {$[\mathrm{MMBtu} / \mathrm{yr}]$} & 9.18 & 9.37 & 9.41 & 9.33 & 9.47 & 9.52 & 9.42 & 9.29 & 9.33 & 9.26 \\
\hline Source Energy Savings & {$[\mathrm{MMBtu} / \mathrm{yr}]$} & 14.12 & 12.6 & 12.26 & 12.91 & 11.82 & $11.41]$ & 12.18 & 13.23 & 12.93 & 13.49 \\
\hline
\end{tabular}




\begin{tabular}{|c|c|c|c|c|c|c|c|c|c|c|c|}
\hline \multicolumn{12}{|c|}{ Albuquerque $2,700 \mathrm{ft}^{2}$ 2-Story Prototype } \\
\hline & & \multirow[b]{2}{*}{ Benchmark } & \multicolumn{9}{|c|}{\begin{tabular}{|c|} 
Single Stud 16" OC \\
\end{tabular}} \\
\hline & & & \begin{tabular}{|c|}
$R-21+$ \\
R-4
\end{tabular} & \begin{tabular}{|c|}
$R-19+$ \\
$R-4$
\end{tabular} & $\begin{array}{c}\mathrm{R}-23+ \\
\mathrm{R}-4\end{array}$ & $\begin{array}{c}\mathrm{R}-21+ \\
\mathrm{R}-6\end{array}$ & \begin{tabular}{|c|} 
R-19 + \\
R-6
\end{tabular} & \begin{tabular}{|c|}
$R-23+$ \\
$R-6$
\end{tabular} & $\begin{array}{c}\mathrm{R}-21+ \\
\mathrm{R}-8 \\
\end{array}$ & $\begin{array}{c}\mathrm{R}-19+ \\
\mathrm{R}-8\end{array}$ & $\begin{array}{c}R-23+ \\
R-8\end{array}$ \\
\hline Energy Related Costs, Annualized & {$[\$ / y r]$} & $\$ 2,248$ & $\$ 2,128$ & $\$ 2,130$ & $\$ 2,133$ & $\$ 2,118$ & $\$ 2,120$ & $\$ 2,124$ & $\$ 2,109$ & $\$ 2,110$ & $\$ 2,116$ \\
\hline Total Source Energy & [MMBtu/yr] & 199.43 & 186.87 & 187.38 & 186.41 & 185.75 & 186.2 & 185.36 & 184.86 & 185.25 & 184.52 \\
\hline Cooling Source Energy (electricity) & {$[\mathrm{MMBtu} / \mathrm{yr}]$} & 15.31 & 13.46 & \begin{tabular}{|l|}
13.51 \\
\end{tabular} & 13.41 & 13.33 & 13.38 & \begin{tabular}{|l|}
13.29 \\
\end{tabular} & 13.23 & 13.27 & 13.2 \\
\hline \begin{tabular}{|l|l|} 
Heating Source Energy (gas) \\
\end{tabular} & {$[\mathrm{MMBtu} / \mathrm{yr}]$} & 64.52 & 55.18 & 55.59 & 54.82 & 54.31 & 54.66 & 54 & 53.61 & 53.92 & 53.33 \\
\hline HVAC Fan Source Energy (electricity & {$[\mathrm{MMBtu} / \mathrm{yr}]$} & 10.63 & 9.24 & 9.29 & 9.19 & 9.12 & 9.17 & 9.08 & 9.03 & 9.07 & 9 \\
\hline \begin{tabular}{|l|} 
Source Energy Savings \\
\end{tabular} & {$[\mathrm{MMBtu} / \mathrm{yr}]$} & 0 & 12.56 & 12.05 & 13.02 & 13.68 & 13.23 & 14.07 & 14.57 & 14.18 & 14.91 \\
\hline
\end{tabular}

\begin{tabular}{|c|c|c|c|c|c|c|c|c|c|c|c|}
\hline & \multirow[b]{2}{*}{$\begin{array}{c}\text { Double } \\
\text { Stud }\end{array}$} & \multicolumn{9}{|c|}{ Single Stud 24" OC } \\
\hline & & & $\begin{array}{c}\text { R-21 + } \\
\text { R-6 }\end{array}$ & $\begin{array}{c}\text { R-19 + } \\
\text { R-6 }\end{array}$ & $\begin{array}{c}\text { R-23 + } \\
\text { R-6 }\end{array}$ & $\begin{array}{c}\text { R-21 + } \\
\text { R-4 }\end{array}$ & \begin{tabular}{|c|} 
R-19 + \\
R-4
\end{tabular} & $\begin{array}{c}\text { R-23 + } \\
\text { R-4 }\end{array}$ & $\begin{array}{c}\text { R-21 + } \\
\text { R-8 }\end{array}$ & $\begin{array}{c}\text { R-19 + } \\
\text { R-8 }\end{array}$ & $\begin{array}{c}\text { R-23 + } \\
\text { R-8 }\end{array}$ \\
\hline Energy Related Costs, Annualized & {$[\$ / y r]$} & $\$ 2,184$ & $\$ 2,116$ & $\$ 2,118$ & $\$ 2,123$ & $\$ 2,125$ & $\$ 2,128$ & $\$ 2,131$ & $\$ 2,109$ & $\$ 2,111$ & $\$ 2,116$ \\
\hline Total Source Energy & {$[\mathrm{MMBtu} / \mathrm{yr}]$} & 183.23 & 185.01 & 185.45 & 184.65 & 185.97 & 186.48 & 185.55 & 184.26 & 184.62 & 183.93 \\
\hline Cooling Source Energy (electricity) & {$[\mathrm{MMBtu} / \mathrm{yr}]$} & 13.03 & 13.22 & 13.26 & 13.19 & 13.32 & 13.37 & 13.28 & 13.15 & 13.18 & 13.12 \\
\hline Heating Source Energy (gas) & {$[\mathrm{MMBtu} / \mathrm{yr}]$} & 52.35 & 53.76 & 54.11 & 53.46 & 54.52 & 54.93 & 54.18 & 53.15 & 53.45 & 52.89 \\
\hline HVAC Fan Source Energy (electricity & {$[\mathrm{MMBtu} / \mathrm{yr}]$} & 8.86 & 9.04 & 9.09 & 9.01 & 9.14 & 9.19 & 9.1 & 8.97 & 9 & 8.93 \\
\hline Source Energy Savings & {$[\mathrm{MMBtu} / \mathrm{yr}]$} & 16.2 & 14.42 & 13.98 & 14.78 & 13.46 & 12.95 & 13.88 & 15.17 & 14.81 & 15.5 \\
\hline
\end{tabular}

\begin{tabular}{|c|c|c|c|c|c|c|c|c|c|c|c|}
\hline \multicolumn{12}{|c|}{ Phoenix 2,700 $\mathrm{ft}^{2}$ 2-Story Prototype } \\
\hline & & \multirow[b]{2}{*}{ Benchmark } & \multicolumn{9}{|c|}{ Single Stud 16" OC } \\
\hline & & & $\begin{array}{c}\text { R-21 + } \\
\text { R-4 }\end{array}$ & $\begin{array}{c}\text { R-19 + } \\
\text { R-4 }\end{array}$ & $\begin{array}{c}\mathrm{R}-23+ \\
\mathrm{R}-4\end{array}$ & \begin{tabular}{|c|} 
R-21 + \\
R-6
\end{tabular} & $\begin{array}{c}\text { R-19 + } \\
\text { R-6 }\end{array}$ & $\begin{array}{c}\text { R-23 + } \\
\text { R-6 }\end{array}$ & $\begin{array}{c}R-21+ \\
R-8\end{array}$ & $\begin{array}{c}\text { R-19 + } \\
\text { R-8 }\end{array}$ & $\begin{array}{c}\text { R-23 + } \\
\text { R-8 }\end{array}$ \\
\hline Energy Related Costs, Annualized & {$[\$ / y r]$} & $\$ 2,422$ & $\$ 2,292$ & $\$ 2,295$ & $\$ 2,297$ & $\$ 2,281$ & $\$ 2,283$ & $\$ 2,287$ & $\$ 2,273$ & $\$ 2,274$ & $\$ 2,279$ \\
\hline Total Source Energy & {$[\mathrm{MMBtu} / \mathrm{yr}]$} & 203.73 & \begin{tabular}{|l|}
191.57 \\
\end{tabular} & 192.06 & 191.14 & 190.52 & 190.94 & 190.15 & 189.67 & 190.05 & 189.36 \\
\hline Cooling Source Energy (electricity) & {$[\mathrm{MMBtu} / \mathrm{yr}]$} & 74.19 & \begin{tabular}{|l|}
66.51 \\
\end{tabular} & 66.83 & 66.23 & \begin{tabular}{|l|}
65.83 \\
\end{tabular} & 66.1 & 65.59 & 65.28 & 65.52 & 65.07 \\
\hline Heating Source Energy (gas) & {$[\mathrm{MMBtu} / \mathrm{yr}]$} & 8.54 & 6.1 & 6.19 & 6.02 & 5.91 & 5.99 & 5.85 & 5.76 & 5.83 & 5.71 \\
\hline HVAC Fan Source Energy (electricity & {$[\mathrm{MMBtu} / \mathrm{yr}]$} & 18.94 & 16.92 & 17 & 16.85 & 16.74 & 16.81 & 16.67 & 16.59 & 16.66 & 16.54 \\
\hline Source Energy Savings & {$[\mathrm{MMBtu} / \mathrm{yr}]$} & 0 & 12.16 & 11.67 & 12.59 & 13.21 & 12.79 & 13.58 & 14.06 & 13.68 & 14.37 \\
\hline
\end{tabular}

\begin{tabular}{|c|c|c|c|c|c|c|c|c|c|c|c|}
\hline & \multirow{2}{*}{$\begin{array}{c}\text { Double } \\
\text { Stud }\end{array}$} & \multicolumn{9}{|c|}{ Single Stud 24" OC } \\
\hline & & & $\begin{array}{c}\mathrm{R}-21+ \\
\mathrm{R}-6\end{array}$ & $\begin{array}{c}\text { R-19 + } \\
\text { R-6 }\end{array}$ & $\begin{array}{c}\text { R-23 + } \\
\text { R-6 }\end{array}$ & \begin{tabular}{|c|} 
R-21 + \\
R-4
\end{tabular} & $\begin{array}{c}\text { R-19+ } \\
\text { R-4 }\end{array}$ & $\begin{array}{c}R-23+ \\
R-4\end{array}$ & $\begin{array}{c}\text { R-21 + } \\
\text { R-8 }\end{array}$ & $\begin{array}{c}\text { R-19 + } \\
\text { R-8 }\end{array}$ & $\begin{array}{c}\text { R-23 + } \\
\text { R-8 }\end{array}$ \\
\hline Energy Related Costs, Annualized & {$[\$ / y r]$} & $\$ 2,345$ & $\$ 2,280$ & $\$ 2,282$ & $\$ 2,286$ & $\$ 2,289$ & $\$ 2,291$ & $\$ 2,294$ & $\$ 2,273$ & $\$ 2,274$ & $\$ 2,279$ \\
\hline Total Source Energy & [MMBtu/yr] & 187.85 & 189.8 & 190.2 & 189.46 & 190.7 & 191.17 & 190.3 & 189.1 & 189.43 & 188.8 \\
\hline Cooling Source Energy (electricity) & [MMBtu/yr] & 64.14 & 65.38 & 65.65 & 65.16 & 65.97 & 66.28 & 65.71 & 64.92 & 65.14 & 64.72 \\
\hline \begin{tabular}{|l|} 
Heating Source Energy (gas) \\
\end{tabular} & {$[\mathrm{MMBtu} / \mathrm{yr}]$} & 5.38 & 5.76 & 5.82 & 5.7 & 5.91 & 5.99 & 5.84 & 5.64 & 5.69 & 5.59 \\
\hline HVAC Fan Source Energy (electricity & {$[\mathrm{MMBtu} / \mathrm{yr}]$} & 16.29 & 16.62 & 16.69 & 16.56 & 16.78 & 16.86 & 16.71 & 16.5 & 16.56 & 16.45 \\
\hline Source Energy Savings & {$[\mathrm{MMBtu} / \mathrm{yr}]$} & 15.88 & 13.93 & 13.53 & 14.27 & 13.03 & 12.56 & 13.43 & 14.63 & 14.3 & 14.93 \\
\hline
\end{tabular}


